\title{
Soil properties and not inputs control carbon : nitrogen : phosphorus ratios in cropped soils in the long term
}

\author{
Emmanuel Frossard $^{1}$, Nina Buchmann ${ }^{2}$, Else K. Bünemann ${ }^{1}$, Delwende I. Kiba ${ }^{1,3}$, François Lompo $^{3}$, \\ Astrid Oberson ${ }^{1}$, Federica Tamburini ${ }^{1}$, and Ouakoltio Y. A. Traoré ${ }^{1,3}$ \\ ${ }^{1}$ Group of Plant Nutrition, Institute of Agricultural Sciences, ETH Zurich, Switzerland \\ ${ }^{2}$ Group of Grassland Sciences, Institute of Agricultural Sciences, ETH Zurich, Switzerland \\ ${ }^{3}$ INERA, Ouagadougou, Burkina Faso \\ Correspondence to: Emmanuel Frossard (emmanuel.frossard@usys.ethz.ch)
}

Received: 19 August 2015 - Published in SOIL Discuss.: 21 September 2015

Accepted: 13 February 2016 - Published: 29 February 2016

\begin{abstract}
Stoichiometric approaches have been applied to understand the relationship between soil organic matter dynamics and biological nutrient transformations. However, very few studies have explicitly considered the effects of agricultural management practices on the soil $\mathrm{C}: \mathrm{N}: \mathrm{P}$ ratio. The aim of this study was to assess how different input types and rates would affect the $\mathrm{C}: \mathrm{N}: \mathrm{P}$ molar ratios of bulk soil, organic matter and microbial biomass in cropped soils in the long term. Thus, we analysed the $\mathrm{C}, \mathrm{N}$, and $\mathrm{P}$ inputs and budgets as well as soil properties in three long-term experiments established on different soil types: the Saria soil fertility trial (Burkina Faso), the Wagga Wagga rotation/stubble management/soil preparation trial (Australia), and the DOK (bio-Dynamic, bio-Organic, and "Konventionell") cropping system trial (Switzerland). In each of these trials, there was a large range of $\mathrm{C}, \mathrm{N}$, and $\mathrm{P}$ inputs which had a strong impact on element concentrations in soils. However, although $\mathrm{C}: \mathrm{N}: \mathrm{P}$ ratios of the inputs were highly variable, they had only weak effects on soil $\mathrm{C}: \mathrm{N}: \mathrm{P}$ ratios. At Saria, a positive correlation was found between the N : P ratio of inputs and microbial biomass, while no relation was observed between the nutrient ratios of inputs and soil organic matter. At Wagga Wagga, the $\mathrm{C}: \mathrm{P}$ ratio of inputs was significantly correlated to total soil $\mathrm{C}: \mathrm{P}, \mathrm{N}: \mathrm{P}$, and $\mathrm{C}: \mathrm{N}$ ratios, but had no impact on the elemental composition of microbial biomass. In the DOK trial, a positive correlation was found between the $\mathrm{C}$ budget and the $\mathrm{C}$ to organic $\mathrm{P}$ ratio in soils, while the nutrient ratios of inputs were not related to those in the microbial biomass. We argue that these responses are due to differences in soil properties among sites. At Saria, the soil is dominated by quartz and some kaolinite, has a coarse texture, a fragile structure, and a low nutrient content. Thus, microorganisms feed on inputs (plant residues, manure). In contrast, the soil at Wagga Wagga contains illite and haematite, is richer in clay and nutrients, and has a stable structure. Thus, organic matter is protected from mineralization and can therefore accumulate, allowing microorganisms to feed on soil nutrients and to keep a constant $\mathrm{C}: \mathrm{N}: \mathrm{P}$ ratio. The DOK soil represents an intermediate situation, with high nutrient concentrations, but a rather fragile soil structure, where organic matter does not accumulate. We conclude that the study of $\mathrm{C}, \mathrm{N}$, and $\mathrm{P}$ ratios is important to understand the functioning of cropped soils in the long term, but that it must be coupled with a precise assessment of element inputs and budgets in the system and a good understanding of the ability of soils to stabilize $\mathrm{C}, \mathrm{N}$, and $\mathrm{P}$ compounds.
\end{abstract}




\section{Introduction}

Ecological stoichiometry has been defined by Sterner and Elser (2002) as "the balance of multiple chemical substances in ecological interactions and processes, or the study of this balance". The elements most often considered in ecological stoichiometry are carbon $(\mathrm{C})$, nitrogen $(\mathrm{N})$, and phosphorus (P). Ecological stoichiometry has delivered very interesting insights into growth and trophic relations in aquatic systems (algae, plankton) as well as in terrestrial systems (plants, animals) (Sterner and Elser, 2002; Elser et al., 2010; Ågren, 2008; Hessen et al., 2013; Güsewell, 2004).

The principles of ecological stoichiometry have been used in soil science to understand organic matter stabilization and mineralization (e.g. McGill and Cole, 1981; Stewart and Tiessen, 1987; Parton et al., 1988; Gressel et al., 1996). Cleveland and Liptzin (2007) reported an average $\mathrm{C}: \mathrm{N}: \mathrm{P}$ molar ratio of $186: 13: 1$ for bulk soils (Table 1), which was close to the Redfield ratio $(160: 16: 1)$ found for plankton in marine environments (Redfield, 1958), and an average $\mathrm{C}: \mathrm{N}: \mathrm{P}$ molar ratio of $60: 7: 1$ in soil microbial biomass (Table 1). In a global analysis of soil microbial $\mathrm{C}, \mathrm{N}$, and $\mathrm{P}, \mathrm{Xu}$ et al. (2013) reported an average microbial $\mathrm{C}: \mathrm{N}: \mathrm{P}$ molar ratio of $46: 6: 1$, which was close to the ratio provided by Cleveland and Liptzin (2007), but also described large variations in microbial $\mathrm{C}, \mathrm{N}$, and $\mathrm{P}$ concentrations and molar ratios between biomes. Whereas Xu et al. (2013) were able to calculate global stocks of soil microbial $\mathrm{C}$ and $\mathrm{N}$, this was not possible for microbial $\mathrm{P}$ due to the lack of data and the use of different methods. Hartman and Richardson (2013) compared soil microbial $\mathrm{C}, \mathrm{N}$, and $\mathrm{P}$ concentrations and the $\mathrm{C}: \mathrm{N}: \mathrm{P}$ ratios of soil microbial biomass from a wide range of soil samples to the metabolic quotient, i.e. respiration per unit microbial biomass. These authors reported an average $\mathrm{C}: \mathrm{N}: \mathrm{P}$ molar ratio of $402: 21: 1$ for bulk soils and an average $C: N: P$ molar ratio of $96: 9: 1$ for the soil microbial pool. Hartman and Richardson (2013) did not observe any relation between nutrient ratios of the microbial biomass and the soil. Furthermore, they were able to show that $\mathrm{N}$ availability constrained microbial growth, whereas $\mathrm{P}$ availability constrained microbial activity (Hartman and Richardson, 2013).

The differences in $\mathrm{C}: \mathrm{N}: \mathrm{P}$ ratios between pools and studies, as summarized in Table 1, call for some remarks. Firstly, the soil $\mathrm{C}: \mathrm{N}: \mathrm{P}$ ratio reported by Kirkby et al. (2011) for Australian soils is higher in $\mathrm{C}$ and $\mathrm{N}$ than in other studies. This is explained by the fact that Kirkby et al. (2011) exclusively considered organic $\mathrm{P}\left(\mathrm{P}_{\mathrm{o}}\right)$, which makes up between 29 and $65 \%$ of total P in soil (Harrison, 1987), whereas other studies reported total P. Secondly, the bulk soils in Table 1 have very high $\mathrm{C}: \mathrm{P}$ and high $\mathrm{N}: \mathrm{P}$ ratios compared to those in microbial biomass, suggesting that microbial biomass is richer in $\mathrm{P}$ and $\mathrm{N}$ than total soil organic matter. This was reported by Stewart and Tiessen (1987) and can be explained by the need for $\mathrm{P}$ in ribosomes and for $\mathrm{N}$ in proteins (Sterner and Elser, 2002; Loladze and Elser, 2011).

The ratios of $\mathrm{C}, \mathrm{N}$, and $\mathrm{P}$ in soil microbial biomass can provide information about the ability of microorganisms to adapt to available resources (Fanin et al., 2013), to immobilize nutrients in organic forms, and to release nutrients through organic matter mineralization (He et al., 1997; Heuck et al., 2015). Mooshammer et al. (2014) summarized the processes controlling the $\mathrm{C}: \mathrm{N}: \mathrm{P}$ ratio of soil microorganisms feeding on different substrates. These processes are (i) adaptation of the elemental composition of the microbial biomass to the substrate in a non-homeostatic behaviour, e.g. by changing the microbial community structure (Makino et al., 2003), (ii) uptake of nutrients released by exo-enzymes (Kertesz and Frossard, 2015), (iii) a change in microbial nutrient use efficiency with, for example, sulfolipids replacing phospholipids in microbial membranes under P-limiting conditions (Van Mooy et al., 2006), and (iv) the additional supply of nutrients related to, for example, the dissolution of mineral phases by saprotrophic fungi and to $\mathrm{N}_{2}$-fixing bacteria (Kertesz and Frossard, 2015). Fanin et al. (2013) showed that the C:N : P ratios of soil microorganisms resembled that of the watersoluble fraction of the litter they were provided with and not that of the bulk litter, showing the importance of the available fraction in determining nutrient uptake and molar ratios in microorganisms. Heuck et al. (2015) compared the effect of $\mathrm{C}, \mathrm{N}$, and $\mathrm{P}$ additions to samples of two forest soils and showed that the $\mathrm{C}: \mathrm{N}: \mathrm{P}$ ratio of microorganisms was affected in the nutrient-poor but not in the nutrientrich soil. In the studies by Fanin et al. and Heuck et al., changes in microbial $\mathrm{C}: \mathrm{N}: \mathrm{P}$ ratios were partly accompanied by changes in microbial community structure. Griffiths et al. (2012) and Chen et al. (2014) showed that different P fertilization regimes did not modify the $\mathrm{C}: \mathrm{N}: \mathrm{P}$ ratio of soil microorganisms in the long term on a grazed pasture, while they strongly modified the microbial $\mathrm{P}$ and $\mathrm{C}$ concentrations and the soil microbial community composition. Finally, Mouginot et al. (2014) showed that the N : P ratios of fungi and bacteria isolated from grassland leaf litter were similar, whereas the $\mathrm{C}: \mathrm{N}$ and $\mathrm{C}: \mathrm{P}$ ratios were higher in fungi than in bacteria, which is in line with observations of higher $\mathrm{P}$ concentrations in bacteria than in fungi made by Bünemann et al. (2008a, 2011).

The $\mathrm{C}: \mathrm{N}: \mathrm{P}$ ratio in soil organic matter can provide relevant information about the impact of nutrient limitations on $\mathrm{C}$ sequestration in soil and about the role of microorganisms in determining soil organic matter composition. Van Groenigen et al. (2006) provided empirical evidence that increased $\mathrm{C}$ sequestration in soils would only occur if $\mathrm{N}$ were added at much higher levels than typically deposited with precipitation. More recently, Kirkby et al. (2011) analysed the C, $\mathrm{N}$, and $\mathrm{P}_{\mathrm{o}}$ concentrations of the stable organic matter in Australian soils, defined as the organic matter remaining in soil after removal of all plant residues. They observed strong linear positive correlations between $C$ and $\mathrm{N}$ as well as $C$ and $P_{o}$ 
Table 1. Average $\mathrm{C}: \mathrm{N}: \mathrm{P}$ molar ratios in bulk soil (total $\mathrm{C}$, total $\mathrm{N}$, and total $\mathrm{P}$, unless otherwise mentioned) and in soil microbial biomass reported in selected studies.

\begin{tabular}{llll}
\hline Reference & Number of soils & Bulk soil & Microbial biomass \\
\hline Cleveland and Liptzin (2007) & 186 & $186: 13: 1$ & $60: 7: 1^{1}$ \\
Xu et al. (2013) & 3422 & $287: 17: 1^{2}$ & $46: 6: 1^{3}$ \\
Hartman and Richardson (2013) & 355 & $402: 21: 1$ & $96: 9: 1^{1}$ \\
Griffiths et al. (2012) & 36 & $219: 18: 1$ & $36: 5: 1^{1}$ \\
Kirkby et al. (2011) & $59^{4}$ & $\mathrm{C}: \mathrm{N}: \mathrm{P}_{\mathrm{o}}: 488: 35: 1^{5}$ & $\mathrm{nd}^{6}$ \\
Kirkby et al. (2011) & $527^{7}$ & $\mathrm{C}: \mathrm{N}: \mathrm{P}_{\mathrm{o}}$ ranged from $39: 3: 1$ to $452: 34: 1^{5}$ & $\mathrm{nd}$ \\
Mouginot et al. (2014) & 45 (fungi) $^{8}$ & & $106: 13: 1$ \\
Mouginot et al. (2014) & 42 (bacteria) $^{8}$ & & $72: 16: 1$ \\
\hline
\end{tabular}

\footnotetext{
${ }^{1}$ Cleveland and Liptzin (2007), Hartman and Richardson (2013) and Griffiths et al. (2012) explicitly included conversion factors (0.45 for microbial C and microbial $\mathrm{N}$ and 0.40 for microbial P) in their calculations for microbial C, N, and P. ${ }^{2} \mathrm{Xu}$ et al. (2013) considered soil organic carbon and not total C. ${ }^{3} \mathrm{Xu}$ et al. (2013) did not explicitly mention the use of conversion factors for the calculation of soil microbial C, N, and P concentrations. ${ }^{4}$ Kirkby et al.'s collection of Australian soils. ${ }^{5}$ Kirkby et al. considered soil organic P and not total P. ${ }^{6}$ Not determined. ${ }^{7}$ Kirkby et al.'s collection of "international" soils. ${ }^{8}$ Data were obtained on 45 strains of fungi and 42 strains of bacteria isolated from grassland leaf litter and grown in the laboratory on artificial media.
}

in these soils. This allowed them to calculate an average molar $C: N: P_{0}$ ratio of stable soil organic matter of $483: 35: 1$ (Table 1). Then, Kirkby et al. (2011) compared the results obtained from their Australian soils to those of soils published in other studies (in their data set called "international soils"). This comparison confirmed the $\mathrm{C}: \mathrm{N}$ ratio of about 14 observed in the Australian soils, but showed a large range of $C: P_{o}$ ratios in the "international soils" (between 41 and 454). This variation was explained by different methods used to assess soil organic P in the other studies (Kirkby et al., 2011), but might also have resulted from the greater diversity of environmental and management conditions in the "international soils". Finally, Kirkby et al. $(2013,2014)$ showed that more $\mathrm{C}$ was transferred from straw to stable soil organic matter when soils were incubated in the presence of $\mathrm{N}$ and $\mathrm{P}$ added in water-soluble forms, and that this greater $\mathrm{C}$ transfer rate was accompanied by greater microbial $\mathrm{C}$ concentration. This last point is in agreement with findings suggesting that a large fraction of soil organic matter is of microbial origin (Six et al., 2006; Schmidt et al., 2011; Miltner et al., 2012; Cotrufo et al., 2013; Trivedi et al., 2013).

This introduction shows that there is already a significant body of information on the $\mathrm{C}, \mathrm{N}$, and $\mathrm{P}$ relationships in soils, and it illustrates how this knowledge is used. However, as pointed out by Mulder et al. (2013), we lack information on P (i) because of an overall lack of data on P and (ii) because of the different methods used to measure microbial and organic P. Furthermore, although published papers consider soils from agricultural systems (Kirkby et al., 2011; Hartman and Richardson, 2013; Xu et al., 2013), the impacts of agricultural practices are very rarely studied (Mulder et al., 2013; Griffiths et al., 2012). These should, however, be considered as agricultural systems can receive large amounts of $\mathrm{C}, \mathrm{N}$, and $\mathrm{P}$ through net photosynthesis, symbiotic $\mathrm{N}_{2}$ fixation, and organic and mineral fertilizer additions, as well as through seeds and wet and dry atmospheric deposition. At the same time, they export large amounts of elements not only through crop products but also due to element losses to the atmosphere, groundwater, surface water, and deep soil horizons. The sum of all inputs minus the sum of all outputs reported for a given surface has been defined as the soil system budget for a given nutrient (Oenema et al., 2003). Such inputs and soil surface nutrient budgets need to be considered when studying the ecological stoichiometry of a cropped soil, as they reflect the substrate the soil biota will feed on.

Here, we asked whether $\mathrm{C}, \mathrm{N}$, and $\mathrm{P}$ inputs into cropped soils affect the $\mathrm{C}, \mathrm{N}$, and $\mathrm{P}$ concentrations and the molar $\mathrm{C}: \mathrm{N}: \mathrm{P}$ ratio of the bulk soil (total $\mathrm{C}$ : total $\mathrm{N}$ : total $\mathrm{P}$ ratio), soil organic matter (total $\mathrm{C}:$ total $\mathrm{N}: \mathrm{P}_{\mathrm{o}}$ ratio) and soil microbial biomass (microbial $\mathrm{C}$ : microbial $\mathrm{N}$ : microbial $\mathrm{P}$ ratio, abbreviated $\mathrm{Cmic}: \mathrm{Nmic}:$ Pmic) in the long term. We hypothesized that the $\mathrm{C}: \mathrm{N}: \mathrm{P}$ ratios of soil pools (total, organic, and microbial) will be affected more by soil properties (such as texture and mineralogy) than by element inputs, whereas element concentrations of soil pools will be strongly affected by element inputs and soil system budgets. We focused on three long-term experiments studying the impact of various agricultural practices on crop yield and soil fertility: the Saria field experiment in Burkina Faso (Pieri, 1989), the Wagga Wagga trial in Australia (Heenan et al., 1994), and the DOK field trial in Switzerland (Mäder et al., 2002). For each trial, we estimated the yearly $\mathrm{C}, \mathrm{N}$, and $\mathrm{P}$ inputs to the soil as well as the $\mathrm{C}, \mathrm{N}$, and $\mathrm{P}$ soil system budgets and compared them to the $\mathrm{C}, \mathrm{N}$, and $\mathrm{P}$ contents and molar ratios in the bulk soil, organic matter, and microbial biomass measured in the upper soil horizon. As we are dealing with three very different field trials, we present the respective descriptions, results and discussions successively, first for the Saria trial, then for the Wagga Wagga trial, and then for the DOK trial. After these trial-specific assessments, we compare and discuss results across trials. 


\section{The Saria field experiment}

\subsection{Description of the Saria field experiment}

This long-term field experiment was established in Saria, Burkina Faso, in 1960 and is still running. The trial has been described by a number of authors (Pieri, 1989; Sedogo, 1993; Bonzi, 2002; Hien, 2004; Lompo, 2009; Zida et al., 2011; Kiba, 2012). It was established with the aim of evaluating the effect of different fertilization regimes, stubble management, and crop rotation on soil fertility. Saria (altitude: $300 \mathrm{~m}$ a.s.l.; $12^{\circ} 16^{\prime} \mathrm{N}, 2^{\circ} 9^{\prime} \mathrm{W}$ ) is located in the central plateau of Burkina Faso, $82 \mathrm{~km}$ southwest of the capital city Ouagadougou and $23 \mathrm{~km}$ north of Koudougou. The climate is characterized by a dry season from October to May and a single rainy season from June to September. The Harmattan wind blowing in November and December brings dust from the Sahara to Saria (Lesschen et al., 2007). The annual average rainfall is $800 \mathrm{~mm}$, but highly variable both in quantity and distribution; the annual potential evaporation is $2000 \mathrm{~mm}$; and the average annual temperature is close to $30^{\circ} \mathrm{C}$ (Zougmoré et al., 2004). The field trial has been established on a gentle slope on a soil developed on granitic parent material from the Precambrian. The soil of the site has been classified as a Ferric Acrisol (FAO ISRIC ISSS, 1998) by Hien (2004). The first $10 \mathrm{~cm}$ of the profile contains $11.7 \%$ clay, $25.7 \%$ silt, and $62.6 \%$ sand. The clay fraction is dominated by kaolinite, while the mineralogy of the total soil is dominated by quartz (Hien, 2004).

The field trial has a split-plot design with six replicates with different fertilization regimes as main treatments and different crop rotations as secondary treatments. The plots of the rotation treatments are $10 \mathrm{~m}$ long and $8.4 \mathrm{~m}$ wide. The fertilization treatments considered in the present study are CON (control, no nutrient input since 1960), MIN1 (low nutrient input in the form of mineral fertilizer: $37 \mathrm{~kg} \mathrm{Nha}^{-1}$ year ${ }^{-1}, 10 \mathrm{~kg} \mathrm{Pha}^{-1}$ year $^{-1}$, $11.6 \mathrm{~kg} \mathrm{~K} \mathrm{ha}^{-1}$ year $^{-1}$ ), MINFYM1 (same low mineral fertilizer input as in MIN1 plus $5 \mathrm{t}$ fresh weight manure per hectare every second year), MIN2 (high mineral fertilizer input: $60 \mathrm{~kg} \mathrm{Nha}^{-1}$ year $^{-1}, 10 \mathrm{~kg} \mathrm{Pha}^{-1}$ year $^{-1}$, $36.5 \mathrm{~kg} \mathrm{Kha}^{-1}$ year $^{-1}$ ), and MINFYM2 (same high mineral fertilizer input as in MIN2 plus $40 \mathrm{t}$ fresh weight manure per hectare every second year). Note that the actual manure inputs have been kept constant since 1976 but varied before then (from 1960 to 1976, the treatment MINFYM1 was receiving $5 \mathrm{t}_{\text {manure }} \mathrm{ha}^{-1}$ year $^{-1}$; the treatment MINFYM2 received $5 \mathrm{t}_{\text {manure }} \mathrm{ha}^{-1}$ year $^{-1}$ from 1960 to 1963 and then $40 \mathrm{t}_{\text {manure ha }}^{-1}$ year $^{-1}$ from 1963 to 1976). Manure is incorporated just before sowing sorghum (Sorghum bicolor). Manure is produced as a mix of cow excreta (faeces and urine) and straw stored outside in a pile during 6 months before being brought to the field. The $\mathrm{N}$ mineral fertilizer is urea, with one half added at sowing and the other half at stem elongation/flowering. $\mathrm{P}$ and $\mathrm{K}$ mineral fertilizers are added in water-soluble forms. This paper focuses on the ro- tation sorghum cowpea (Vigna unguiculata), which has been established in 1975, following a sorghum groundnut (Arachis hypogea) rotation. During the last few years before present, the cultivars were Sariasso 14 for sorghum and KVX-396-45-2D for cowpea. The entire trial received $1.5 \mathrm{tha}^{-1}$ of lime in 1978 and again in 1988 to limit acidification. No lime has been added since 1988. Plant residues (straw) were systematically exported from the field. In this study, we considered only the replicates $1,2,3$, and 4 . Replicates 5 and 6 were not considered because of their strongly degraded soil structure and regular water logging.

Element inputs $(\mathrm{C}, \mathrm{N}$, and $\mathrm{P})$ in the soil-plant system were estimated in $\mathrm{kg} \mathrm{ha}^{-1}$ year $^{-1}$ for the period 1975-2010 as the sum of elements added by net photosynthesis (C), symbiotic $\mathrm{N}_{2}$ fixation $(\mathrm{N})$, seeds $(\mathrm{C}, \mathrm{N}, \mathrm{P})$, organic and mineral fertilizers $(\mathrm{C}, \mathrm{N}, \mathrm{P})$, and dust and rainfall $(\mathrm{N}$ and $\mathrm{P})$. The outputs of $\mathrm{N}$ and $\mathrm{P}$ from the soil-plant system in $\mathrm{kg} \mathrm{ha}^{-1}$ year $^{-1}$ were estimated as the sum of elements removed from the plot as exported plant products (grain and straw) and lost to water, atmosphere, and deep soil horizons. As $\mathrm{C}$ losses through, for example, soil respiration could not be quantified, $\mathrm{C}$ outputs were not assessed. The difference between inputs and outputs provided an estimate of the soil system budget for $\mathrm{N}$ and P (Oenema et al., 2003). Details about these calculations as well as on soil and plant analyses are presented in the Supplement. The detailed inputs outputs are presented in Table S3 for the Saria field experiment.

\subsection{Results and discussion}

\subsubsection{Element inputs and budgets in Saria}

Annual $\mathrm{C}$ inputs varied from less than $1 \mathrm{tha}^{-1} \mathrm{year}^{-1}$ to almost $9 \mathrm{tha}^{-1}$ year $^{-1}$ (Table 2). They were low in the CON, MIN1, and MIN2 treatments and highest in the MINFYM2 treatment. Roots were the main $\mathrm{C}$ input, except in MINFYM2, where farmyard manure provided most of the $\mathrm{C}$ input (Table S3). Annual N inputs varied by a factor of 38, from about $10 \mathrm{~kg} \mathrm{Nha}^{-1}$ in CON to $388 \mathrm{~kg} \mathrm{Nha}^{-1}$ in MINFYM2. Finally, annual $\mathrm{P}$ inputs varied by a factor of almost 90 , from $0.8 \mathrm{~kg} \mathrm{Pha}^{-1}$ in CON to $70 \mathrm{~kg} \mathrm{Pha}^{-1}$ in MINFYM2. Both $\mathrm{N}$ and $\mathrm{P}$ inputs were dominated by manure and fertilizers applications (Table S3). As a consequence of these widely varying inputs, the average $\mathrm{C}: \mathrm{N}: \mathrm{P}$ molar ratio of inputs varied from $3280: 33: 1$ in the CON treatment to $330: 12: 1$ in the MINFYM2 treatment.

The $\mathrm{N}$ budget was negative in all treatments except for MINFYM2. This was due to the limited amount of $\mathrm{N}$ fixed from the atmosphere by cowpea and to the high gaseous $\mathrm{N}$ losses in the treatments receiving mineral fertilizers. The limited amount of $\mathrm{N}$ fixed by cowpea observed in our study is in agreement with Bonzi (2002), who reported that the proportion of $\mathrm{N}$ in the cowpea derived from the atmosphere (Ndfa \%) was about $40 \%$ in the CON and MIN1 treatments, yielding a total amount of $\mathrm{N}$ fixed varying from 17 
Table 2. Average $\mathrm{C}, \mathrm{N}$, and $\mathrm{P}$ in inputs and $\mathrm{C}: \mathrm{N}: \mathrm{P}$ molar ratios in inputs; $\mathrm{N}$ and $\mathrm{P}$ outputs; and soil system budgets (in $\mathrm{kg} \mathrm{ha}^{-1} \mathrm{year}^{-1}$ ) for soil-plant systems subjected to different treatments in the field experiment at Saria, Burkina Faso, for the period 1975-2010.

\begin{tabular}{llrrrrr}
\hline Treatments & & CON $^{1}$ & MINFYM1 & MIN1 & MINFYM2 & MIN2 \\
\hline Total inputs & $\mathrm{C}$ & 987 & 3607 & 1939 & 8914 & 2342 \\
& $\mathrm{~N}$ & 11.5 & 90.9 & 55.4 & 388 & 77.0 \\
& $\mathrm{P}$ & 0.8 & 17.6 & 10.8 & 69.9 & 10.8 \\
& $\mathrm{C}: \mathrm{N}:$ P molar ratio & $3280: 33: 1$ & $522: 11: 1$ & $465: 11: 1$ & $312: 12: 1$ & $561: 16: 1$ \\
\hline Total outputs & $\mathrm{N}$ & 42.1 & 109 & 82.9 & 199 & 107 \\
& $\mathrm{P}$ & 2.9 & 11.9 & 7.0 & 20.4 & 8.4 \\
\hline Soil system budget & $\mathrm{N}$ & -31 & -18 & -27 & 189 & -30 \\
& $\mathrm{P}$ & -2.1 & 5.7 & 3.8 & 49.4 & 2.4 \\
\hline
\end{tabular}

${ }^{1} \mathrm{CON}$ : no mineral or organic fertilizer input; MINFYM1: low application rates of mineral fertilizer and cattle manure $\left(37 \mathrm{~kg} \mathrm{Nha}^{-1} \mathrm{year}^{-1}\right.$, $10 \mathrm{~kg} \mathrm{Pha}^{-1}$ year $^{-1}, 11.6 \mathrm{~kg} \mathrm{Kha}^{-1}$ year $^{-1}$ as mineral fertilizer plus $5 \mathrm{t}$ manure ha ${ }^{-1}$ every second year); MIN1: low application rate of mineral fertilizer ( $37 \mathrm{~kg} \mathrm{~N} \mathrm{ha}^{-1}$ year $^{-1}, 10 \mathrm{~kg} \mathrm{Pha}^{-1}$ year $^{-1}, 11.6 \mathrm{~kg} \mathrm{~K} \mathrm{ha}^{-1}$ year $\left.^{-1}\right)$; MINFYM2: high application rates of mineral fertilizer and cattle manure $60 \mathrm{~kg} \mathrm{Nha}^{-1}$ year ${ }^{-1}, 10 \mathrm{~kg} \mathrm{Pha}^{-1}$ year $^{-1}, 36.5 \mathrm{~kg} \mathrm{~K} \mathrm{ha}^{-1}$ year-1 as mineral fertilizer plus 40 t manure ha ${ }^{-1}$ every second year); MIN2 high application rate of mineral fertilizer $\left(60 \mathrm{~kg} \mathrm{Nha}^{-1}\right.$ year $^{-1}, 10 \mathrm{~kg} \mathrm{Pha}^{-1}$ year $^{-1}, 36.5 \mathrm{~kg} \mathrm{~K} \mathrm{ha}^{-1}$ year $\left.^{-1}\right)$.

to $60 \mathrm{~kg} \mathrm{Nha}^{-1}$ year $^{-1}$. A negative $\mathrm{P}$ budget was observed in CON, while the maximum budget was observed in MINFYM2. However, the $\mathrm{N}$ and $\mathrm{P}$ budgets only took into account limited $\mathrm{N}$ losses by leaching and no $\mathrm{P}$ losses to water, whereas these losses might have been significant in the MINFYM2 treatment. The $\mathrm{C}, \mathrm{N}$, and $\mathrm{P}$ inputs were significantly correlated with each other, $\mathrm{C}$ inputs were correlated with the $\mathrm{N}$ and $\mathrm{P}$ budgets, and $\mathrm{N}$ and $\mathrm{P}$ budgets were correlated with each other (Table S4).

\subsubsection{Relations between $\mathrm{C}, \mathrm{N}$, and $\mathrm{P}$ inputs; $\mathrm{N}$ and $\mathrm{P}$ budgets; and soil properties in Saria}

The treatments had significant effects on most of the studied soil properties (Table 3 ). Usually, MINFYM2 yielded the highest values and CON the lowest. Most of the soil variables (except $\mathrm{pH}$ and microbial $\mathrm{C}$ ) were linearly positively related to the $\mathrm{C}$ inputs (at least $p<0.05$ for all regressions, Table S4). The same soil properties were related to the logarithm of the $\mathrm{N}$ budgets and linearly related to the $\mathrm{P}$ budgets (at least $p<0.05$ for all correlations). The treatments also affected soil $\mathrm{pH}$, with the lowest values observed in the treatments receiving only mineral fertilizers and the highest in the treatments receiving manure. Although the design of the trial does not allow differentiating between the effects of $\mathrm{P}$ addition and manure input, our results suggest that the combined addition of manure and mineral fertilizers is a driver for increased biomass production and nutrient availability as well as for buffering against acidification. These results strongly support the integrated soil fertility management for tropical soils proposed by Vanlauwe et al. (2010).

\subsubsection{Relations between $\mathrm{C}, \mathrm{N}$, and $\mathrm{P}$ inputs; $\mathrm{N}$ and $\mathrm{P}$ budgets; and soil nutrient ratios in Saria}

The soil $\mathrm{C}: \mathrm{N}$ ratio varied between 9.6 and 10.8 (Table 3). Similarly, the soil $\mathrm{C}: \mathrm{P}$ ratio ranged between 39.5 and 58.6, and the $\mathrm{N}: \mathrm{P}$ ratio between 4.0 and 5.6. The $\mathrm{C}: \mathrm{P}_{\mathrm{o}}$ ratio was higher, because of the low $\mathrm{P}_{\mathrm{o}}$ concentration, and varied between 181 and 396. The bulk soil and organic nutrient ratios were not related to the nutrient ratios of the inputs and they were not related to the $\mathrm{N}$ and $\mathrm{P}$ budgets. The fact that the $\mathrm{C}: \mathrm{N}: \mathrm{P}$ ratios of the bulk soil or the organic soil pools were not related to the $\mathrm{C}: \mathrm{N}: \mathrm{P}$ ratios of the inputs suggests that the interplay between microbial degradation and element stabilization in the soil organic and mineral phases drives the $\mathrm{C}: \mathrm{N}: \mathrm{P}$ ratio of soil pools. However, given the limited ability of this soil to store organic matter, linked to its mineralogy dominated by quartz and kaolinite, its very low aggregate stability in water (Dutartre et al., 1993), and the high air and thus soil temperatures favouring high mineralization rates in the rainy season (Parton et al., 2015), organic matter stabilization is probably minimal in this soil. Therefore the microbial processes control the element ratios of the soil pools. The soil $\mathrm{C}: \mathrm{P}$ and $\mathrm{N}: \mathrm{P}$ molar ratios of all treatments were lower than the average values reported in Table 1, which can also be explained by the limited ability of this soil to retain $\mathrm{C}$ and $\mathrm{N}$.

The Cmic : Nmic ratio was highly significantly affected by the treatments $(p<0.01)$, whereas the treatment effects on the Cmic: Pmic and Nmic: Pmic ratios were almost significant $(p<0.05$ and $p<0.06)$ (Table 3 ). This suggests that microorganisms had a non-homeostatic behaviour and that their nutrition was affected by the treatments. The microbial $\mathrm{N}: \mathrm{P}$ ratios were lower than the $\mathrm{N}: \mathrm{P}$ ratios of inputs, but these two variables were positively correlated which each other $(p<0.01$; note that this relationship was still valid at $p<0.1$ when the data point for CON was removed) (Fig. 1). Fur- 
Table 3. Effects of different treatments on selected soil properties for the $0-10 \mathrm{~cm}$ horizon and on soil C : N : P molar ratios at Saria, Burkina Faso. Soil pH, total C, and total N were reported in Kiba (2012) for soils sampled in 2009; the other analyses were done on soils sampled in 2013.

\begin{tabular}{|c|c|c|c|c|c|c|c|c|c|}
\hline \multicolumn{3}{|l|}{ Treatments } & \multirow{2}{*}{$\begin{array}{r}\mathrm{CON} \\
5.88\end{array}$} & \multirow{2}{*}{$\begin{array}{r}\text { MINFYM1 } \\
5.77\end{array}$} & \multirow{2}{*}{$\begin{array}{r}\text { MIN1 } \\
5.36\end{array}$} & \multirow{2}{*}{$\begin{array}{r}\text { MINFYM2 } \\
6.57\end{array}$} & \multirow{2}{*}{$\begin{array}{r}\text { MIN2 } \\
5.49\end{array}$} & \multirow{2}{*}{\multicolumn{2}{|c|}{$\begin{array}{l}\begin{array}{l}\text { Statistics } \\
\text { treatment effect }\end{array} \\
* * * 2\end{array}$}} \\
\hline $\mathrm{pH}$ water & & & & & & & & & \\
\hline Total C & $\mathrm{C}$ & $\mathrm{g} \mathrm{kg}^{-1}$ & 1.61 & 2.74 & 1.91 & 4.65 & 2.21 & 0.21 & $* * *$ \\
\hline Total N & $\mathrm{N}$ & $\mathrm{mg} \mathrm{kg}^{-1}$ & 196 & 305 & 225 & 505 & 244 & 18.7 & $* * *$ \\
\hline Total P & $\mathrm{P}$ & $\mathrm{mg} \mathrm{kg}^{-1}$ & 77.7 & 130 & 125 & 205 & 120 & 10.7 & $* * *$ \\
\hline Organic P & Po & $\mathrm{mg} \mathrm{kg}^{-1}$ & 13.0 & 17.9 & 27.3 & 51.4 & 17.1 & 1.94 & $* * *$ \\
\hline Inorganic $\mathrm{P}$ & $\mathrm{Pi}$ & $\mathrm{mg} \mathrm{kg}^{-1}$ & 64.7 & 112 & 97.4 & 154 & 103 & 10.6 & $* *$ \\
\hline Dissolved N & $\mathrm{N}$ & $\mathrm{mg} \mathrm{kg}^{-1}$ & 8.21 & 13.6 & 16.3 & 35.9 & 18.4 & 1.54 & $* * *$ \\
\hline Resin P & $\mathrm{P}$ & $\mathrm{mg} \mathrm{kg}^{-1}$ & 2.03 & 13.8 & 10.6 & 29.3 & 7.74 & 1.38 & $* * *$ \\
\hline Microbial C & Cmic & $\mathrm{mg} \mathrm{kg}^{-1}$ & $\mathrm{nd}^{1}$ & 65.7 & 26.7 & 121 & 26.2 & 4.21 & $* * *$ \\
\hline Microbial N & Nmic & $\mathrm{mg} \mathrm{kg}^{-1}$ & 5.52 & 7.82 & 7.47 & 27.68 & 8.03 & 1.57 & $* * *$ \\
\hline Microbial P & Pmic & $\mathrm{mg} \mathrm{kg}^{-1}$ & 0.91 & 3.78 & 4.50 & 14.4 & 3.06 & 1.27 & $* * *$ \\
\hline \multirow[t]{3}{*}{ Molar ratio of total elements } & $C: N$ & & 9.59 & 10.50 & 9.89 & 10.75 & 10.56 & 0.27 & $*$ \\
\hline & $\mathrm{C}: \mathrm{P}$ & & 53.7 & 54.7 & 39.5 & 58.6 & 47.4 & 4.00 & $*$ \\
\hline & $N: P$ & & 5.60 & 5.21 & 4.00 & 5.45 & 4.48 & 0.33 & $*$ \\
\hline \multirow[t]{2}{*}{ Molar ratio of organic elements } & $\mathrm{C}: \mathrm{P}_{\mathrm{O}}$ & & 320 & 396 & 181 & 234 & 333 & 21.9 & $* * *$ \\
\hline & $N: P_{0}$ & & 33.4 & 37.7 & 18.3 & 21.7 & 31.5 & 1.84 & $* * *$ \\
\hline \multirow[t]{3}{*}{ Molar ratio of microbial elements } & Cmic : Nmic & & nd & 9.81 & 4.17 & 5.10 & 3.81 & 0.90 & $* *$ \\
\hline & Cmic : Pmic & & nd & 44.9 & 15.3 & 21.7 & 22.2 & 8.88 & ns $(0.05)$ \\
\hline & Nmic : Pmic & & 13.4 & 4.58 & 3.68 & 4.25 & 5.82 & 1.58 & ns $(0.06)$ \\
\hline
\end{tabular}

${ }^{1}$ nd: not determined; ${ }^{2}$ : ns: not significant $(p>0.05), * p<0.05, * * p<0.01, * * * p<0.001$

Table 4. Average $\mathrm{C}, \mathrm{N}$, and $\mathrm{P}$ in inputs and $\mathrm{C}: \mathrm{N}: \mathrm{P}$ molar ratios in inputs; $\mathrm{N}$ and $\mathrm{P}$ outputs; and $\mathrm{C}$, N, and $\mathrm{P}$ soil system budgets for soil-plant systems subjected to different treatments in the field experiment at Wagga Wagga, Australia, for the period 1979-2000.

\begin{tabular}{|c|c|c|c|c|c|c|c|}
\hline Treatments & & & WL-M-C ${ }^{1}$ & WL-B-C & WW-B-C & WS-M-D & WS-M-C \\
\hline \multirow[t]{4}{*}{ Total inputs } & $\mathrm{C}$ & $\mathrm{tha}^{-1}$ year $^{-1}$ & 6.10 & 5.70 & 5.38 & 7.11 & 7.10 \\
\hline & $\mathrm{N}$ & $\mathrm{kg} \mathrm{ha}^{-1}$ year $^{-1}$ & 85.5 & 85.5 & 6.8 & 129 & 129 \\
\hline & $\mathrm{P}$ & $\mathrm{kg} \mathrm{ha}^{-1}$ year $^{-1}$ & 20.6 & 20.6 & 20.6 & 20.6 & 20.6 \\
\hline & $\mathrm{C}: \mathrm{N}: \mathrm{P}$ & molar ratio & 764:9:1 & 713:9:1 & $673: 0.7: 1$ & $892: 14: 1$ & $891: 14: 1$ \\
\hline \multirow[t]{2}{*}{ Total outputs } & $\mathrm{N}$ & $\mathrm{kg} \mathrm{ha}^{-1}$ year $^{-1}$ & 91.1 & 114 & 90.1 & 54.8 & 53.3 \\
\hline & $\mathrm{P}$ & $\mathrm{kg} \mathrm{ha}^{-1}$ year $^{-1}$ & 8.2 & 10.0 & 9.3 & 6.0 & 5.8 \\
\hline \multirow[t]{4}{*}{ Soil system budgets } & $C^{2}$ & $\mathrm{~kg} \mathrm{ha}^{-1}$ year $^{-1}$ & -199 & -284 & -389 & 185 & 9 \\
\hline & $\mathrm{N}^{2}$ & $\mathrm{~kg} \mathrm{ha}^{-1}$ year $^{-1}$ & -29.0 & -42.0 & -51.0 & 9.0 & -6.0 \\
\hline & $\mathrm{N}$ & $\mathrm{kg} \mathrm{ha}^{-1}$ year $^{-1}$ & -5.56 & -28.3 & -83.3 & 74.0 & 75.5 \\
\hline & $\mathrm{P}$ & $\mathrm{kg} \mathrm{ha}^{-1}$ year $^{-1}$ & 12.4 & 10.6 & 11.3 & 14.6 & 14.8 \\
\hline
\end{tabular}

1 WL-M-C: wheat-lupin rotation with mulch and cultivation; WL-B-C: wheat-lupin rotation with burning and cultivation; WW-B-C: continuous wheat with burning and cultivation; WS-M-D: wheat-subterranean clover rotation with mulch and direct drilling; WS-M-C: wheat-subterranean clover rotation with mulch and cultivation. ${ }^{2}$ Data derived from Heenan et al. (2004) for the $0-10 \mathrm{~cm}$ soil layer.

thermore, the $\mathrm{N}: \mathrm{P}$ ratios of soil microorganisms were almost identical to those observed in the bulk soil in all treatments except CON, where the Nmic : Pmic ratio was higher than the soil $\mathrm{N}: \mathrm{P}$ ratio (Table 3 ). This suggests that, in the absence of fresh residues, as was the case in this study, microorganisms feed on substrate with a $\mathrm{N}: \mathrm{P}$ ratio that is ultimately controlled by the inputs. The fact that the $\mathrm{N}: \mathrm{P}$ ratio of microorganisms is lower than that of the organic pools $\left(\mathrm{N}: \mathrm{P}_{\mathrm{o}}\right)$ suggests that microorganisms are accessing both mineral and organic P pools. Finally, the high microbial $\mathrm{N}: \mathrm{P}$ value observed in the CON treatment compared to the data shown in Table 1 suggests that microorganisms were P-limited in this treatment. This supports the hypothesis of a $\mathrm{P}$ limitation of microorganisms in this treatment proposed by Traoré et al. (2016) based on changes in microbial respiration and biomass production following $\mathrm{C}, \mathrm{N}$, and $\mathrm{P}$ additions to this soil in a short-term incubation experiment. 


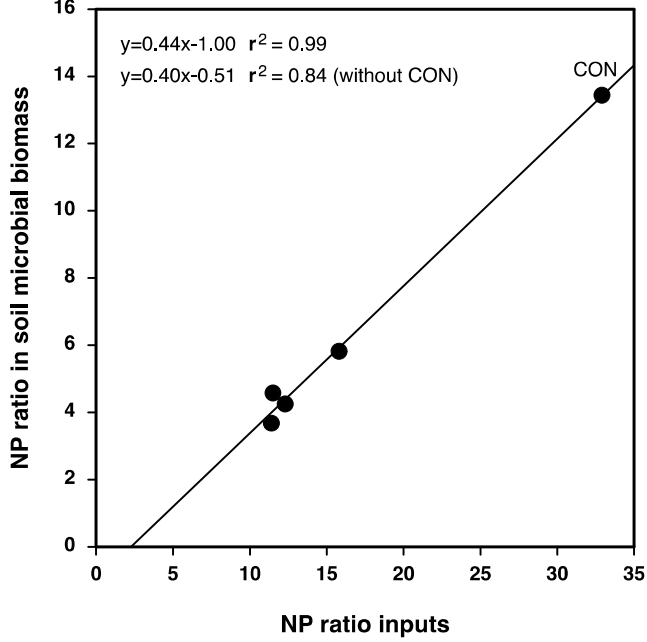

Figure 1. Relationship between the molar $\mathrm{N}: \mathrm{P}$ ratios in the inputs and the molar $\mathrm{N}$ : $\mathrm{P}$ ratios in the soil microbial biomass in the Saria field experiment.

\section{The Wagga Wagga field experiment}

\subsection{Description of the Wagga Wagga field experiment}

The long-term field experiment on crop rotations and stubble and tillage management in Wagga Wagga, NSW, Australia $\left(35^{\circ} 7^{\prime} \mathrm{S}, 147^{\circ} 21^{\prime} \mathrm{E}\right)$, was started in 1979 on a Chromic Luvisol (FAO ISRIC ISSS, 1998) and terminated in 2005. The soil developed on a carbonated aeolian material from the last ice age. The trial was situated at an altitude of $220 \mathrm{~m}$ a.s.l. and experienced a climate with hot, dry summers and cold winters. Mean annual rainfall was $570 \mathrm{~mm}$, and mean annual temperature $15.9^{\circ} \mathrm{C}$. At the beginning of the trial, the soil $\mathrm{pH}$ in $\mathrm{H}_{2} \mathrm{O}$ of the top $5 \mathrm{~cm}$ soil was 5.5 (Bünemann et al., 2008b), and the soil contained $29 \%$ clay, $15 \%$ silt, and $56 \%$ sand in the top $10 \mathrm{~cm}$ (Heenan and Chan, 1992). Soil mineralogy was dominated by quartz, kaolinite, illite, and iron oxides (mostly haematite) (M. Conyers, personal communication, 2015). The experiment had a randomized block design with six blocks and 16 treatments, and a plot size of $4.3 \mathrm{~m}$ by $50 \mathrm{~m}$ (Chan and Heenan, 1993). Three crop rotations (wheatwheat (Triticum aestivum), wheat-lupin (Lupinus angustifolius), and wheat-subterranean clover (Trifolium subterraneum)) were included in the original design, in combination with different stubble and tillage management treatments. Each rotation phase was present each year, with blocks 1, 3, and 5 sown with wheat in 1979 and blocks 2, 4, and 6 in 1980. In treatments with stubble retention, stubble was slashed in summer, i.e. between late December and early March, while stubble burning was done in April. Cultivations in autumn were done either with offset disc harrows to $0.10 \mathrm{~m}$ (mulched treatments) or a scarifier to $0.10 \mathrm{~m}$ (treatments with cultivation). The only mineral fertilizer input was in the form of superphosphate $\left(20 \mathrm{~kg} \mathrm{Pha}^{-1}\right.$ year $\left.^{-1}\right)$, added yearly with the seeds at sowing to each crop (including subterranean clover). The subterranean clover was mown once or twice in spring/early summer and left on the plots as mulch. More details on the experimental design can be found in publications from the trial addressing, for example, yields (Heenan et al., 1994, 2000), soil organic matter (Chan et al., 1992; Heenan et al., 1995; Heenan et al., 2004), and soil pH changes (Heenan and Taylor, 1995). For this study, the following treatments were selected to cover the entire range of soil organic C levels (Heenan et al., 2004): wheat-lupin with mulch and cultivation (WL-M-C), wheat-lupin with burning and cultivation (WL-B-C), continuous wheat with burning and cultivation (WW-B-C), wheat-subterranean clover with mulching and direct drilling (WS-M-D), and wheatsubterranean clover with mulching and cultivation (WS-MC).

The $\mathrm{C}, \mathrm{N}$, and $\mathrm{P}$ inputs and $\mathrm{N}$ and $\mathrm{P}$ budgets were calculated as described for the Saria field experiment (see above), but also taking into account fire-related losses. The details of these calculations as well as of the soil analyses are presented in the Supplement. As in the Saria trial, it was difficult to estimate $\mathrm{C}$ losses during residue decomposition and due to soil respiration. However, as changes in soil $\mathrm{C}$ and $\mathrm{N}$ concentrations had been measured and modelled in the 0 $10 \mathrm{~cm}$ between 1979 and 2000 (Heenan et al., 2004), we used the slope of the linear changes of $\mathrm{C}$ and $\mathrm{N}$ stocks with time $\left(\mathrm{kg} \mathrm{ha}^{-1}\right.$ year $\left.^{-1}\right)$ in the different treatments as proxies for the annual soil system budgets for $\mathrm{C}$ and $\mathrm{N}$. The detailed inputs and outputs are presented in Table S5 for the Wagga Wagga field experiment.

\subsection{Results and discussion}

\subsubsection{C, N, P inputs and budgets in the Wagga Wagga trial}

The estimated $\mathrm{C}$ inputs ranged between 5.4 and $7.1 \mathrm{tha}^{-1}$ year $^{-1}$, with a maximum observed in the WS-M-D treatment and a minimum in the WW-B-C treatment (Table 4). The estimated $\mathrm{N}$ inputs varied by a factor of almost 18 , ranging between about $7 \mathrm{~kg} \mathrm{Nha}^{-1}$ year $^{-1}$ in the WW-B-C treatment and $129 \mathrm{~kg} \mathrm{Nha}^{-1}$ year $^{-1}$ in the WS-M-D treatment. Most of these $\mathrm{N}$ inputs came from symbiotic fixation. The estimated $\mathrm{P}$ inputs were identical in all treatments $\left(20.6 \mathrm{~kg} \mathrm{Pha}^{-1}\right.$ year $\left.^{-1}\right)$. As a consequence, the average $\mathrm{C}: \mathrm{N}: \mathrm{P}$ molar ratio of inputs varied from $892: 13.8: 1$ in the WS-M-D treatment to $673: 0.73: 1$ in the WW-B-C treatment.

The $\mathrm{C}$ budget derived from the data presented by Heenan et al. (2004) showed the strongest $C$ depletion in the WW-B-C treatment $\left(-0.39 \mathrm{tC} \mathrm{ha}^{-1}\right.$ year $\left.^{-1}\right)$, and the strongest $\mathrm{C}$ increase in the WS-M-D treatment (almost $0.18 \mathrm{tC} \mathrm{ha}^{-1}$ year $^{-1}$ ) (Table 4). The $\mathrm{N}$ budgets of the different treatments calculated in the present study for the entire soil profile were higher than those derived from Heenan et 
al. (2004), except for the treatment WW-B-C, for which the N budget estimated in this study was lower. Except for the treatment WW-B-C, the difference between the two $\mathrm{N}$ budgets can be explained by the fact that Heenan et al. (2004) considered only $0-10 \mathrm{~cm}$, whereas the budget in this study considered the entire soil profile and therefore included $\mathrm{N}$ stored deeper than $10 \mathrm{~cm}$ (e.g. in the form of roots). The higher $\mathrm{C}$ and $\mathrm{N}$ budgets in the treatment WS-M-D were due to $\mathrm{N}_{2}$ fixation, mulch retention and direct drilling, while the lowest budget reported for WW-B-C was due to regular cultivation, absence of significant $\mathrm{N}_{2}$ fixation, and mulch burning. The $\mathrm{P}$ budgets were positive as reported by Bünemann et al. (2006). The $\mathrm{C}$ and $\mathrm{N}$ budgets derived from Heenan et al. (2004) were significantly correlated with each other $(p<0.05$; Table S6) and both budgets were significantly correlated with the $\mathrm{P}$ budget calculated in this study ( $p<0.05$; Table S6).

\subsubsection{Relations between C, N, P inputs and budgets and soil properties in Wagga Wagga}

For most soil variables, highest values were observed in the treatment WS-M-D, followed by WS-M-C and then the other treatments (Table 5). Most of the soil variables, except total $\mathrm{P}$, resin $\mathrm{P}$, and microbial $\mathrm{P}$, were related to the $\mathrm{C}$ and $\mathrm{N}$ budgets derived from Heenan et al. (2004). The positive linear relationships observed between total $\mathrm{C}$, total $\mathrm{N}$, organic $\mathrm{P}$, dissolved $\mathrm{N}$, microbial $\mathrm{C}$, microbial $\mathrm{N}$, and the $\mathrm{C}$ budget ( $p<0.05$ in each case, Table S6) are linked to the accumulation of organic matter (Bünemann et al., 2008b). The increased total $\mathrm{C}$, total $\mathrm{N}$, and organic $\mathrm{P}$ concentrations in WS$\mathrm{M}-\mathrm{D}$ are probably related to the improved aggregate stability, porosity, and infiltration rate compared to WW-B-C (Zhang et al., 2007).

\subsubsection{Relations between C, N, P inputs and budgets and soil nutrient ratios in Wagga Wagga}

The soil $\mathrm{C}: \mathrm{N}$ ratio varied between 13.7 and 19.2 , the $\mathrm{C}: \mathrm{P}$ ratio between 62 and 137 , and the $\mathrm{N}: \mathrm{P}$ ratio between 3.2 and 10.0 (Table 5). The soil $\mathrm{C}: \mathrm{P}$ ratios were lower than the $\mathrm{C}: \mathrm{P}$ ratios of the inputs in all treatments. Similarly, the soil $\mathrm{N}: \mathrm{P}$ ratios were lower than the $\mathrm{N}: \mathrm{P}$ ratios in inputs in all treatments except in the WW-B-C treatment, where soil N : P was higher. This means that the interplay between degradation and stabilization drives the soil $\mathrm{C}: \mathrm{N}: \mathrm{P}$ ratios in Wagga Wagga, similar to Saria. The $\mathrm{C}: \mathrm{P}$ ratio of the inputs was positively correlated to the $\mathrm{C}$ budget derived from Heenan et al. (2004), while the $C: P$ ratio of the inputs was negatively correlated to soil $\mathrm{C}: \mathrm{N}$ and positively to soil $\mathrm{C}: \mathrm{P}$ and $\mathrm{N}: \mathrm{P}$ ratios $(p<0.05$ in each case, Table S6) (Fig. 2). These variations reflect the faster accumulation of $\mathrm{C}$ compared to $\mathrm{P}$, and the importance of symbiotic $\mathrm{N}_{2}$ fixation, leading to faster $\mathrm{N}$ accumulation compared to $\mathrm{C}$. The soil $\mathrm{C}: \mathrm{P}$ and $\mathrm{N}: \mathrm{P}$ molar ratios of all treatments at the Wagga Wagga site were lower than the average values reported in Table 1, while the
$\mathrm{C}: \mathrm{P}_{\mathrm{o}}$ and $\mathrm{N}: \mathrm{P}_{\mathrm{O}}$ ratios were only slightly lower than values reported by Kirkby et al. (2011) for Australian soils. The lower $\mathrm{C}: \mathrm{P}$ and $\mathrm{N}: \mathrm{P}$ ratios might be explained by a relative accumulation of $\mathrm{P}$ in inorganic forms due to fertilizer inputs and the presence of iron oxides, such as haematite, known to have a high sorption capacity for phosphate (Wang et al., 2013). The $C: N$ ratio was also relatively high, especially in the cropping systems in which mulch was burnt. This result supports the suggestion by Heenan et al. (2004) that burning results in higher $\mathrm{N}$ than $\mathrm{C}$ losses.

The microbial ratios were not affected by the different treatments (Table 5). Furthermore, no relationships were observed between the $\mathrm{C}: \mathrm{N}, \mathrm{C}: \mathrm{P}$ and $\mathrm{N}: \mathrm{P}$ ratios of inputs and those of soil microorganisms. This suggests that the microorganisms in this soil have a homeostatic behaviour. The microbial $\mathrm{C}: \mathrm{P}$ and $\mathrm{N}: \mathrm{P}$ ratios found in the Wagga Wagga soils were higher than the average values reported in Table 1 . Given the high concentration in available $\mathrm{P}$, we assume that there was no $\mathrm{P}$ limitation for microbial growth in this soil. The fungi/bacteria ratio of $0.09-0.14$ in this soil (Bünemann et al., 2008b) suggests a high proportion of fungi relative to its organic matter concentration (Frostegård and Bååth, 1996). Given the typically high $\mathrm{C}: \mathrm{P}$ ratios of fungi (Table 1), this might explain the wide microbial $\mathrm{C}: \mathrm{P}$ ratios in the Wagga Wagga soils.

\section{The DOK field experiment}

\subsection{Description of the field experiment}

The DOK (bio-Dynamic, bio-Organic, and "Konventionell") long-term field experiment on the comparison of organic and conventional cropping systems was started in Therwil, near Basel, Switzerland $\left(7^{\circ} 33^{\prime} \mathrm{E}, 47^{\circ} 30^{\prime} \mathrm{N}\right.$; $300 \mathrm{~m}$ a.s.l.), in 1978 and is still running (Mäder et al., 2006). The mean annual temperature of the site is $9.7^{\circ} \mathrm{C}$ and the mean annual precipitation $791 \mathrm{~mm}$ (period 1864-2007) (Leifeld et al., 2009). The soil is a Haplic Luvisol (FAO ISRIC ISSS, 1998), developed on an alluvial loess deposit. Its first $30 \mathrm{~cm}$ horizon has $15 \%$ sand, $70 \%$ silt, and $15 \%$ clay. The clay fraction is dominated by smectite, illite, and mica (D. Tessier, personal communication, 2006). The experimental design of the DOK experiment, including a detailed description of the management practices, is presented in Mäder et al. (2002, 2006). In brief, the field experiment includes cropping systems which differ mainly in fertilization and plant protection strategies. We selected the following treatments as they cover the entire range of inputs: the non-fertilized control (NON), which has received no fertilizer input since 1978; the conventional control (MIN) with exclusively mineral fertilizers since 1984 (from 1978 to 1984, this treatment did not receive any fertilizer); the bio-organic (ORG) system receiving slightly aerobically rotted farmyard manure and slurry; and the conventional system (MINORG) with stacked farmyard manure and slurry as well as mineral fertilizers as a supple- 
Table 5. Effects of different treatments on selected soil properties for the $0-5 \mathrm{~cm}$ horizon and on $\mathrm{C}: \mathrm{N}: \mathrm{P}$ molar ratios in soil sampled in 2005 at Wagga Wagga, Australia (all data are from Bünemann et al., 2008b).

\begin{tabular}{|c|c|c|c|c|c|c|c|c|c|}
\hline Treatments & & & WL-M-C & WL-B-C & WW-B-C & WS-M-D & WS-M-C & SEM & $\begin{array}{l}\text { Statistics } \\
\text { treatment effect }\end{array}$ \\
\hline pH water & & & 5.25 & 5.35 & 5.61 & 5.09 & 5.17 & 0.05 & $* * *$ \\
\hline Total C & $\mathrm{C}$ & $\mathrm{g} \mathrm{kg}^{-1}$ & 13.9 & 12.1 & 11.5 & 28.9 & 17.0 & 1.07 & $* * *$ \\
\hline Total N & $\mathrm{N}$ & $\mathrm{g} \mathrm{kg}^{-1}$ & 0.97 & 0.77 & 0.70 & 2.47 & 1.37 & 0.12 & $* * *$ \\
\hline Total P & $\mathrm{P}$ & $\mathrm{mg} \mathrm{kg}^{-1}$ & 435 & 427 & 477 & 546 & 447 & 12.8 & $* * *$ \\
\hline Organic P & $\mathrm{P}_{\mathrm{O}}$ & $\mathrm{mg} \mathrm{kg}^{-1}$ & 134 & 118 & 126 & 191 & 150 & 5.51 & $* * *$ \\
\hline Inorganic $\mathrm{P}$ & $\mathrm{P}_{\mathrm{i}}$ & $\mathrm{mg} \mathrm{kg}^{-1}$ & 301 & 308 & 352 & 355 & 296 & 9.57 & $*$ \\
\hline Dissolved N & $\mathrm{N}$ & $\mathrm{mg} \mathrm{kg}^{-1}$ & 31.7 & 23.5 & 17.4 & 45.1 & 33.2 & 2.94 & $* * *$ \\
\hline Resin P & $\mathrm{P}$ & $\mathrm{mg} \mathrm{kg}^{-1}$ & 35.7 & 42.3 & 43.4 & 38.9 & 35.7 & 2.64 & ns \\
\hline Microbial C & Cmic & $\mathrm{mg} \mathrm{kg}^{-1}$ & 317 & 280 & 3001 & 508 & 404 & 29.8 & $* *$ \\
\hline Microbial N & Nmic & $\mathrm{mg} \mathrm{kg}^{-1}$ & 27.4 & 24.4 & 28.9 & 51.8 & 40.7 & 4.37 & $* *$ \\
\hline Microbial P & Pmic & $\mathrm{mg} \mathrm{kg}^{-1}$ & 4.00 & 5.08 & 6.75 & 10.92 & 7.58 & 1.42 & $*$ \\
\hline \multirow[t]{3}{*}{ Molar ratio of total elements } & $\mathrm{C}: \mathrm{N}$ & & 16.8 & 18.5 & 19.2 & 13.7 & 14.5 & 0.69 & $* * *$ \\
\hline & $\mathrm{C}: \mathrm{P}$ & & 82.7 & 73.5 & 62.1 & 136.9 & 98.3 & 4.06 & $* * *$ \\
\hline & $\mathrm{N}: \mathrm{P}$ & & 4.92 & 3.98 & 3.24 & 10.00 & 6.78 & 0.44 & $* * *$ \\
\hline \multirow[t]{2}{*}{ Molar ratio of organic elements } & $\mathrm{C}: \mathrm{P}_{\mathrm{O}}$ & & 269 & 265 & 235 & 391 & 292 & 10.4 & $* * *$ \\
\hline & $\mathrm{N}: \mathrm{P}_{\mathrm{O}}$ & & 16.0 & 14.3 & 12.3 & 28.6 & 20.1 & 1.11 & $* * *$ \\
\hline \multirow[t]{3}{*}{ Molar ratio of microbial elements } & Cmic : Nmic & & 13.5 & 13.4 & 12.1 & 11.4 & 11.6 & 0.68 & ns \\
\hline & Cmic : Pmic & & 205 & 1427 & 115 & 120 & 137 & 29.9 & ns \\
\hline & Nmic : Pmic & & 15.2 & 10.6 & 9.5 & 10.5 & 11.9 & 2.69 & ns \\
\hline
\end{tabular}
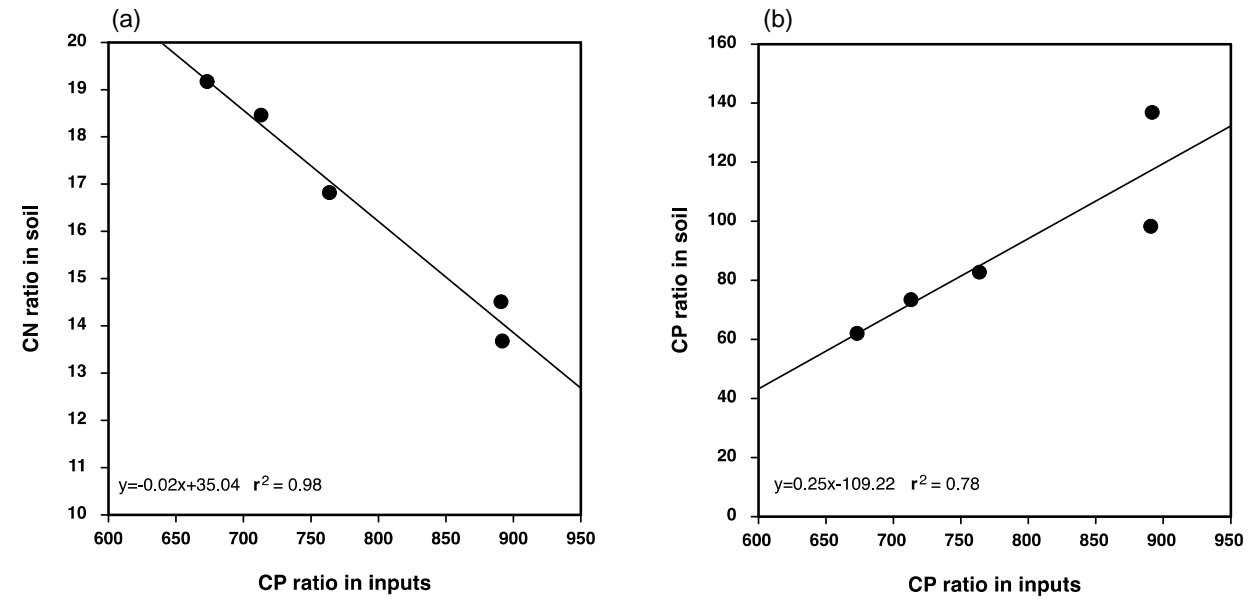

Figure 2. Relationships (a) between the $\mathrm{C}: \mathrm{P}$ molar ratio in inputs and the soil $\mathrm{C}: \mathrm{N}$ molar ratio and (b) between the $\mathrm{C}: \mathrm{P}$ molar ratio in inputs and the soil $\mathrm{C}$ : $\mathrm{P}$ molar ratio in the Wagga Wagga field experiment.

ment. The fertilized treatments MIN, ORG, and MINORG received nutrient forms and amounts that are typical for the respective cropping system (Table S5). For ORG, the amount has been defined since 1992 by the manure production of 1.4 livestock units (LU), while it was 1.2 LU from 1978 until 1991. Nutrient amounts of the conventional treatments MIN and MINORG are defined by the Swiss fertilization guidelines (Flisch et al., 2009, and earlier versions thereof). In MINORG, the manure produced by 1.4 LU (1.2 LU from 1978 until 1991) is supplemented with mineral fertilizers up to the dose recommended by the Swiss fertilization guidelines. The slurries and farmyard manures originate from farms that are managed according to the respective production system (bioorganic and conventional).

The DOK experiment has a split-split-block design in a Latin square with four replicates and a plot size of $5 \mathrm{~m} \times 20 \mathrm{~m}$. The 7-year crop rotation is the same for all cropping systems and the same crop rotation is put in place on three rotation units (rotation units $a, b$, and $c$ ) but with a time shift, so that three of the seven crops are present each year in each cropping system. Since 1999, the crop rotation has included silage maize (Zea mays L.), winter wheat I (Triticum aestivum L.), soybean (Glycine max (L.) Merr.), potato (Solanum tuberosum L.), winter wheat II, and 2 years 
Table 6. Average $\mathrm{C}, \mathrm{N}$, and $\mathrm{P}$ in inputs and $\mathrm{C}: \mathrm{N}$ : P molar ratios in inputs; $\mathrm{N}$ and $\mathrm{P}$ outputs; and $\mathrm{C}$, N, and $\mathrm{P}$ soil system budgets for soil-plant systems subjected to different treatments in the DOK field experiment, Switzerland, for the period 1978-2006.

\begin{tabular}{|c|c|c|c|c|c|c|}
\hline Treatments & & & $\mathrm{NON}^{1}$ & MIN & ORG & MINORG \\
\hline \multirow[t]{4}{*}{ Total inputs } & $\mathrm{C}^{2}$ & tha $^{-1}$ year $^{-1}$ & 0.96 & 1.41 & 2.40 & 2.81 \\
\hline & $\mathrm{N}$ & $\mathrm{kg} \mathrm{ha}^{-1}$ year $^{-1}$ & 81.7 & 184 & 219 & 250 \\
\hline & $\mathrm{P}$ & $\mathrm{kg} \mathrm{ha}^{-1}$ year $^{-1}$ & 0.78 & 30.8 & 27.8 & 41.8 \\
\hline & $C: N: P$ & molar ratio & $3162: 231: 1$ & $118: 13: 1$ & $223: 17: 1$ & $174: 13: 1$ \\
\hline \multirow[t]{2}{*}{ Total outputs } & $\mathrm{N}$ & $\mathrm{kg} \mathrm{ha}^{-1}$ year $^{-1}$ & 154 & 266 & 269 & 323 \\
\hline & $\mathrm{P}$ & $\mathrm{kg} \mathrm{ha}^{-1}$ year $^{-1}$ & 19.8 & 33.8 & 32.8 & 38.8 \\
\hline \multirow[t]{4}{*}{ Soil system budgets } & $\mathrm{C}^{3}$ & $\mathrm{~kg} \mathrm{ha}^{-1}$ year $^{-1}$ & -0.42 & -0.31 & -0.18 & -0.19 \\
\hline & $\mathrm{N}^{4}$ & $\mathrm{~kg} \mathrm{ha}^{-1}$ year $^{-1}$ & $\mathrm{nd}^{5}$ & -29 & -18 & nd \\
\hline & $\mathrm{N}$ & $\mathrm{kg} \mathrm{ha}^{-1}$ year $^{-1}$ & -72.3 & -81.6 & -49.5 & -72.5 \\
\hline & $\mathrm{P}$ & $\mathrm{kg} \mathrm{ha}^{-1}$ year $^{-1}$ & -19.0 & -3.02 & -5.02 & 2.98 \\
\hline
\end{tabular}

1: NON: no organic or mineral fertilizers application; MIN: only mineral fertilizer applications; ORG: only organic fertilizer applications; MINORG: application of both organic and mineral fertilizers. ${ }^{2}$ Data from Leifeld et al. (2009). ${ }^{3}$ Derived from data in Leifeld et al. (2009) for the $0-20 \mathrm{~cm} .{ }^{4}$ Estimations based on data from Bosshard (2007). ${ }^{5}$ nd: not determined.

of grass-clover ley. From 1992 to 1998, the rotation was similar, but instead of a grain legume it included 3 years of grass-clover ley. During the first two crop rotation periods, the DOK contained 3 years of cereals, 1 year of potatoes, 1 year of vegetable crop, and 2 years of grass-clover ley. Soil tillage is similar in all treatments, with regular ploughing to a depth of 18 to $20 \mathrm{~cm}$ before planting of crops. Likewise, the same plant varieties are sown in organic and conventional systems. In NON, plant protection is according to the means allowed in bio-dynamic farming (bio-control, plant extracts), while MIN and MINORG have an integrated plant protection including pesticides, applied when infestation thresholds indicate a need. In ORG, plant protection is with the means allowed in bio-organic farming.

The $\mathrm{N}$ and $\mathrm{P}$ inputs, outputs and budgets from the soilplant systems were assessed as described in the other two field experiments. The details of these calculations as well as of the soil and plant analyses are presented in the Supplement. The annual $\mathrm{C}$ inputs were taken from Leifeld et al. (2009). As a proxy for the soil system $C$ budgets, we used the annual changes in $\mathrm{C}$ stocks in the $0-20 \mathrm{~cm}$ of the soil determined for the different treatments by Leifeld et al. (2009). The detailed inputs outputs are presented in Table S7 for the DOK field experiment.

\subsection{Results and discussion}

\subsubsection{C, N, P inputs and budgets in the DOK trial}

The estimated $\mathrm{C}, \mathrm{N}$, and $\mathrm{P}$ inputs were lowest for NON and highest for MINORG, with MINORG receiving 3 times greater $\mathrm{C}$ and $\mathrm{N}$ inputs and more than 50 times greater $\mathrm{P}$ inputs than NON (Table 6). This was due to mineral fertilizer and/or manure P inputs in MIN, ORG, and MINORG, while symbiotic $\mathrm{N}_{2}$ fixation and $\mathrm{N}$ deposition made significant in- puts to all treatments including NON (Table S7). Estimated average annual inputs by symbiotic $\mathrm{N}_{2}$ fixation ranged between 47 and $80 \mathrm{~kg} \mathrm{Nha}^{-1}$ year $^{-1}$ and underlined the contribution of the 2 to 3 years of legumes in a rotation lasting 7 years. As a consequence of these inputs, the average $\mathrm{C}: \mathrm{N}: \mathrm{P}$ molar ratio of inputs varied from $3162: 231: 1$ in NON to $118: 13.3: 1$ in MIN.

The changes in $\mathrm{C}$ stocks in the $0-20 \mathrm{~cm}$ horizon spread between -0.42 and $-0.18 \mathrm{tC} \mathrm{ha}^{-1}$ year $^{-1}$ in the different treatments (Table 6; Leifeld et al., 2009), but were not statistically different from each other. The estimated $\mathrm{N}$ budgets were also negative. The total $\mathrm{N}$ losses were dominated by $\mathrm{N}$ export by crops. Assuming an annual loss of $\mathrm{N}$ from the NON treatment of $10 \mathrm{~kg} \mathrm{Nha}^{-1}$ year $^{-1}$ to the atmosphere, water bodies, and deep soil horizons, we obtained total $\mathrm{N}$ losses to the environment in the different treatments of the same order of magnitude as found in previous Swiss studies (Spiess et al., 2011). Our estimates of the annual N budgets were, however, more negative than those calculated from Bosshard (2007) based on measured changes in soil $\mathrm{N}$ stocks for the treatments MIN and ORG. This might be because some $\mathrm{N}$ leached to deeper layers might have been taken up by crops and thus been transferred back to the topsoil. The $\mathrm{P}$ budgets were more differentiated, with the only positive budget observed in MINORG and the most negative in NON. The P budgets were similar to those shown by Oehl et al. (2002) for the period 1978-1998 and by Keller et al. (2012) for the period 19782007. Based on these P budgets, Oehl et al. (2002) reported $\mathrm{P}$ transfers between horizons but no significant losses from the profile beyond $50 \mathrm{~cm}$ depth. 
Table 7. Effects of treatments on selected soil properties of the $0-20 \mathrm{~cm}$ horizon and on $\mathrm{C}: \mathrm{N}: \mathrm{P}$ ratios in the fourth crop rotation in the DOK field experiment, Switzerland. The soil $\mathrm{pH}$, total $\mathrm{C}$, and total $\mathrm{N}$ are from Oberson et al. (2013); the other data are unpublished.

\begin{tabular}{|c|c|c|c|c|c|c|c|c|}
\hline \multicolumn{3}{|l|}{ Treatments } & \multirow{2}{*}{$\begin{array}{r}\text { NON } \\
5.79\end{array}$} & \multirow{2}{*}{$\begin{array}{r}\text { MIN } \\
6.61\end{array}$} & \multirow{2}{*}{$\begin{array}{r}\text { ORG } \\
6.43\end{array}$} & \multirow{2}{*}{$\begin{array}{r}\text { MINORG } \\
6.30\end{array}$} & \multirow{2}{*}{$\begin{array}{r}\text { SEM } \\
0.08\end{array}$} & \multirow{2}{*}{$\begin{array}{l}\text { Statistics } \\
\text { treatment effect } \\
* * *\end{array}$} \\
\hline pH water & & & & & & & & \\
\hline Total organic C & $\mathrm{C}$ & $\mathrm{g} \mathrm{kg}^{-1}$ & 9.88 & 11.3 & 12.6 & 12.2 & 0.5 & $* *$ \\
\hline Total N & $\mathrm{N}$ & $\mathrm{g} \mathrm{kg}^{-1}$ & 1.37 & 1.44 & 1.64 & 1.56 & 0.09 & $*$ \\
\hline Total P & $\mathrm{P}$ & $\mathrm{mg} \mathrm{kg}^{-1}$ & 573 & 700 & 699 & 750 & 33 & $*$ \\
\hline Organic $\mathrm{P}$ & $\mathrm{P}_{\mathrm{O}}$ & $\mathrm{mg} \mathrm{kg}^{-1}$ & 351 & 383 & 419 & 403 & 19 & $\mathrm{~ns}$ \\
\hline Inorganic $\mathrm{P}$ & $P_{i}$ & $\mathrm{mg} \mathrm{kg}^{-1}$ & 222 & 317 & 279 & 346 & 20 & $* *$ \\
\hline Mineral N & $\mathrm{N}$ & $\mathrm{mg} \mathrm{kg}^{-1}$ & 5.96 & 5.92 & 5.74 & 5.62 & 0.9 & $\mathrm{~ns}$ \\
\hline Resin $\mathrm{P}$ & $\mathrm{P}$ & $\mathrm{mg} \mathrm{kg}^{-1}$ & 1.7 & 11.4 & 5.3 & 7.9 & 1.4 & $* *$ \\
\hline Microbial C & Cmic & $\mathrm{mg} \mathrm{kg}^{-1}$ & 176 & 208 & 259 & 211 & 21 & $\mathrm{~ns}$ \\
\hline Microbial N & Nmic & $\mathrm{mg} \mathrm{kg}^{-1}$ & 33.0 & 37.4 & 55.3 & 37.8 & 6.4 & $\mathrm{~ns}$ \\
\hline Microbial P & Pmic & $\mathrm{mg} \mathrm{kg}^{-1}$ & 18.8 & 31.7 & 36.5 & 33.3 & 2.7 & $* *$ \\
\hline \multirow[t]{3}{*}{ Molar ratio of total elements } & $\mathrm{C}: \mathrm{N}$ & & 8.39 & 9.17 & 9.00 & 9.14 & 0.17 & $\mathrm{~ns}$ \\
\hline & $\mathrm{C}: \mathrm{P}$ & & 44.5 & 41.7 & 46.7 & 42.0 & 3.0 & $\mathrm{~ns}$ \\
\hline & $N: P$ & & 5.3 & 4.5 & 5.2 & 4.6 & 0.5 & $\mathrm{~ns}$ \\
\hline \multirow[t]{2}{*}{ Molar ratio of organic elements } & $\mathrm{C}: \mathrm{P}_{\mathrm{O}}$ & & 72.7 & 76.2 & 77.8 & 78.1 & 4.3 & $\mathrm{~ns}$ \\
\hline & $\mathrm{N}: \mathrm{P}_{\mathrm{o}}$ & & 8.67 & 8.31 & 8.65 & 8.55 & 0.7 & ns \\
\hline \multirow[t]{3}{*}{ Molar ratio of microbial elements } & Cmic : Nmic & & 6.20 & 6.48 & 5.46 & 6.52 & 0.6 & $\mathrm{~ns}$ \\
\hline & Cmic : Pmic & & 24.3 & 17.2 & 18.5 & 16.8 & 1.7 & $*$ \\
\hline & Nmic : Pmic & & 3.90 & 2.62 & 3.36 & 2.55 & 0.3 & $*$ \\
\hline
\end{tabular}

\subsubsection{Relation between C, N, P inputs and budgets and soil properties in the DOK}

The treatments significantly affected the total $\mathrm{C}, \mathrm{N}$, and $\mathrm{P}$ concentrations; available $\mathrm{P}$; and microbial $\mathrm{P}$ in the soil (Table 7). When statistical differences could be observed between treatments, the lowest values were always found in the treatment NON, while few differences occurred among the fertilized treatments. Total soil $\mathrm{C}$, total soil $\mathrm{N}$, and soil organic $\mathrm{P}$ were related to the $\mathrm{C}$ budget derived from Leifeld et al. (2009) $(p<0.05$ in each case, Table S8). The P budget calculated in this study was significantly related to soil total $\mathrm{P}$ as well as total inorganic $\mathrm{P}(p<0.05$ in each case, Table S8). These results underline the importance of the $\mathrm{C}$ budget for the storage of organic nutrients and the importance of the $\mathrm{P}$ budget for $\mathrm{P}$ storage in inorganic forms. The decrease in soil organic matter concentration over time reported by Leifeld et al. (2009) is probably related to the low aggregate stability of this soil, limiting the ability of the soil to physically protect organic matter, coupled with frequent soil preparation operations, e.g. for weed control (Siegrist et al., 1998; Bosshard et al., 2008).

\subsubsection{Relations between C, N, P inputs and budgets and soil nutrient ratios in the DOK}

Total and organic soil nutrient ratios did not statistically differ between treatments. The bulk soil nutrient ratios $(\mathrm{C}: \mathrm{P}$,
$\mathrm{N}: \mathrm{P}$ ) were lower than the nutrient ratios observed in the inputs. Furthermore the total and organic nutrients ratios in soil were not related to the nutrient ratios in inputs. The only significant regression was observed between the $\mathrm{C}$ budget and the soil $\mathrm{C}: \mathrm{P}_{\mathrm{o}}$ ratio (Fig. 3) $(p<0.05)$. Altogether this shows again that the interplay between degradation and stabilization controls the changes of nutrient ratios from the inputs to the soil. The soil $\mathrm{C}: \mathrm{P}, \mathrm{N}: \mathrm{P}, \mathrm{C}: \mathrm{P}_{\mathrm{o}}$, and $\mathrm{N}: \mathrm{P}_{\mathrm{o}}$ molar ratios of all treatments of the DOK trial were much lower than the average values reported in Table 1 . This can be explained by a relative accumulation of $\mathrm{P}$ and depletion of $\mathrm{C}$ and $\mathrm{N}$ from this soil, which is related to the fact that the soil has been fertilized regularly with $\mathrm{P}$ and that it is not able to physically protect soil organic matter due to its high silt proportion and to the regular soil preparation operations.

The microbial $\mathrm{C}: \mathrm{N}$ ratio was not affected by the treatments, whereas the microbial $\mathrm{C}: \mathrm{P}$ and $\mathrm{N}: \mathrm{P}$ ratios were higher in NON and similar in all other treatments. The microbial $\mathrm{C}: \mathrm{P}$ and $\mathrm{N}: \mathrm{P}$ ratios found in the DOK trial were lower than the average ratios shown in Table 1 . These low values can be explained by the abundance of available $\mathrm{P}$ in the fertilized treatments and/or by $\mathrm{C}$ and/or $\mathrm{N}$ limitations, as this soil is dominated by bacteria (Esperschütz et al., 2007) and $\mathrm{C}$ - and N-limited bacteria have low element ratios (Vrede et al., 2002). 


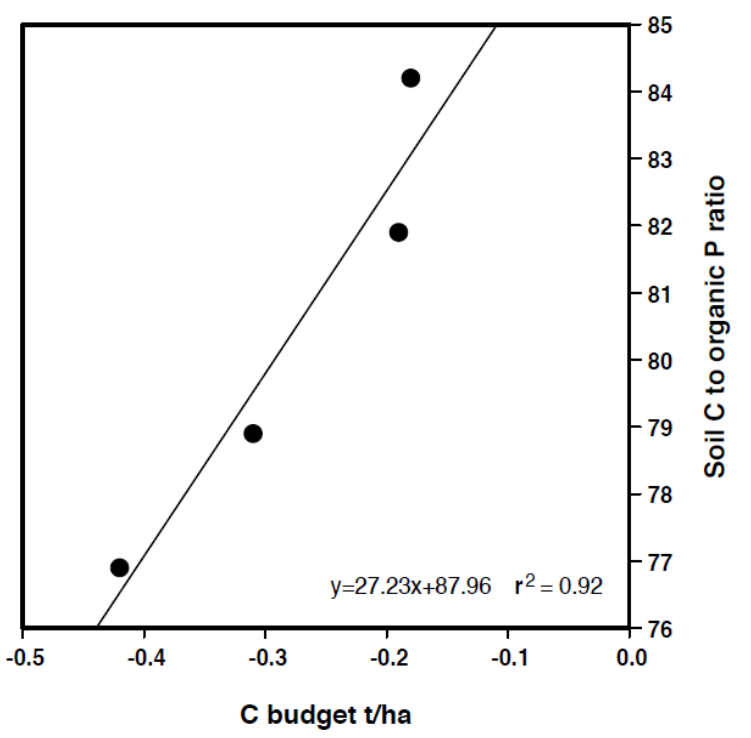

Figure 3. Relation between the $\mathrm{C}$ budget and the soil $\mathrm{C}$ : organic $\mathrm{P}$ molar ratio in the DOK field experiment.

\section{Importance of inputs versus soil properties in determining soil $\mathrm{C}: \mathrm{N}: \mathrm{P}$ ratios}

The analysis of the three field experiments showed that very contrasting inputs over decades had limited impacts on bulk soil, organic and microbial $\mathrm{C}: \mathrm{N}: \mathrm{P}$ ratios, whereas these inputs strongly modified the $\mathrm{C}, \mathrm{N}$, and $\mathrm{P}$ concentrations in soil pools. Therefore, the question arises of what controls the $\mathrm{C}: \mathrm{N}: \mathrm{P}$ ratios in these soils. Soil $\mathrm{C}$ and $\mathrm{N}$ concentrations were highly correlated with each other (Fig. 4a), but each soil showed a specific relationship. Although the slopes of these regressions were similar, the intercepts were different. The relationships between $\mathrm{N}$ and $\mathrm{P}_{\mathrm{o}}$ also showed soil-specific trajectories (Fig. 4b), but both the slopes and the intercepts of the equations differed among soils. Similar observations can be made for the relationships total $\mathrm{C}$ vs. $\mathrm{P}_{\mathrm{o}}$ (Tables S4, S6, and S8) and Nmic vs. Pmic (Fig. 5). These specific trajectories suggest that soil properties have a determining influence on soil organic and microbial nutrient ratios. Indeed, these results show that a change in management will lead to changes in organic and microbial $\mathrm{C}, \mathrm{N}$, and $\mathrm{P}$ concentrations along the regression models determined for each soil. It is interesting to note that, in Fig. 5, the treatment NON from the DOK trial is located close to the treatment MINFYM2 of the Saria trial. This suggests that only extreme treatments (no fertilization in the past 30 years in the DOK or massive fertilizer inputs in Saria) can significantly affect microbial nutrient ratios. The number of soils studied here is too limited for a full statistical assessment, but the soil properties that seem to control organic matter and $\mathrm{P}$ accumulation are the type and content of clay minerals and oxides, soil structural stability (Frossard et al., 2000; Six et al., 2006), and the soil microbial community (Mouginot et al., 2014).
Can the changes in soil nutrient ratios as affected by management seen in this paper be explained by the use of different methods for soil analyses? While the same methods were used to measure total $\mathrm{C}$ and $\mathrm{N}$, microbial $\mathrm{C}$ and $\mathrm{N}$, resin $\mathrm{P}$, and microbial $\mathrm{P}$ in each trial, soil organic $\mathrm{P}$ was measured after an extraction with $\mathrm{NaOH}-\mathrm{EDTA}$ (Bowman and Moir, 1993) in the Saria samples while using the Saunders and Williams method in the Wagga Wagga and DOK samples (Saunders and Williams, 1955) (Supplement). This choice was due to the fact that the Saunders and Williams method gave extremely low values in the Saria samples (Supplement). In the soils of the two other trials, the opposite results were obtained, as the Saunders and Williams method provided larger estimates of soil organic $\mathrm{P}$ than the $\mathrm{NaOH}-$ EDTA (Bünemann et al., 2008; Keller et al., 2012). For this work, we chose to present the respective largest estimates of soil organic P. Although the use of NaOH-EDTA extractable Po instead of the Saunders and Williams estimate of Po changed the $\mathrm{C}$ : Po and $\mathrm{N}$ : Po ratios in the Wagga Wagga and DOK trials, these changes did not change any of the conclusions presented in this paper.

\section{Applicability of ecological stoichiometry to cropped soils}

Can ecological stoichiometry help to better understand the functioning of cropped soils? Our analysis showed that the study of the $\mathrm{C}: \mathrm{N}: \mathrm{P}$ ratios provide information on how inputs affect soil organic matter and microbial biomass composition and how soil type and clay mineralogy affect the stabilization of organic matter and phosphate. Nevertheless, the applicability of ecological stoichiometry to cropped soils remains limited by the difficulty of precisely assessing $\mathrm{C}, \mathrm{N}$, and $\mathrm{P}$ inputs and budgets at field level in the long term.

Metabolites resulting from the degradation of added organic fertilizers and plant residues can be sorbed onto mineral surfaces and/or can be trapped within aggregates of different sizes (Six et al., 2004; von Lützow et al., 2006; Nesper et al., 2015). Similarly, a variable fraction of mineral $P$ added to soil can be sorbed on surfaces or trapped within aggregates (Sinaj et al., 1997). This stabilization can be long lasting or of short duration, depending on the soil environment and management (Schmidt et al., 2011), and this stabilization can concern single elements (such as $\mathrm{P}$ in phosphate ions, or $\mathrm{C}$ in alcanes), molecules containing two elements ( $\mathrm{C}$ and $\mathrm{N}$ as in proteins or $\mathrm{C}$ and $\mathrm{P}$ as in myo-inositol hexakisphosphate), or compounds containing all three elements (as in microbial or plant products) (Ognalaga et al., 1994; Schmidt et al., 2011). In the absence of fresh residues, the ability of a soil to stabilize $\mathrm{C}, \mathrm{N}$, and $\mathrm{P}$ compounds also controls the availability of these elements to microorganisms (Cotrufo et al., 2013) and finally microbial $\mathrm{C}: \mathrm{N}: \mathrm{P}$ ratio. This was well illustrated in the soils of the field trials considered in the present study. In the soil with the lowest clay content (Saria), which had 

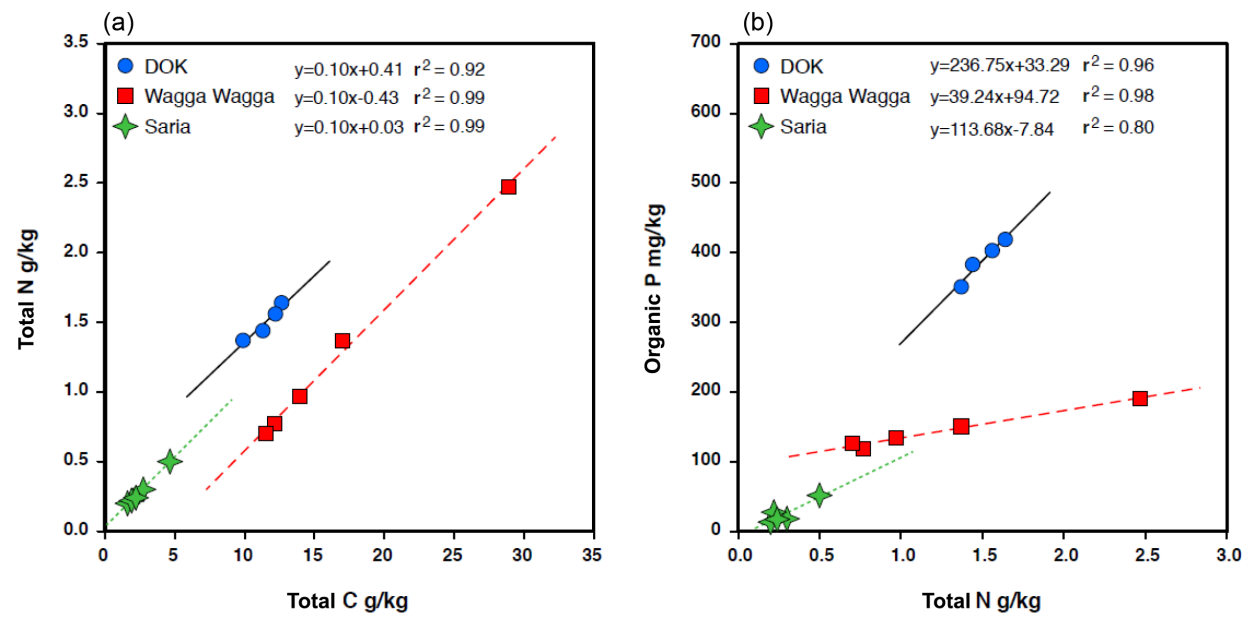

Figure 4. Relationships between soil $\mathrm{C}$ and soil $\mathrm{N}$ concentrations (a) and between soil $\mathrm{N}$ and soil organic $\mathrm{P}$ concentrations (b) in the three field experiments. Points in blue represent DOK, points in red represent Wagga Wagga, and points in green represent Saria. All relations are statistically significant at $p<0.05$.

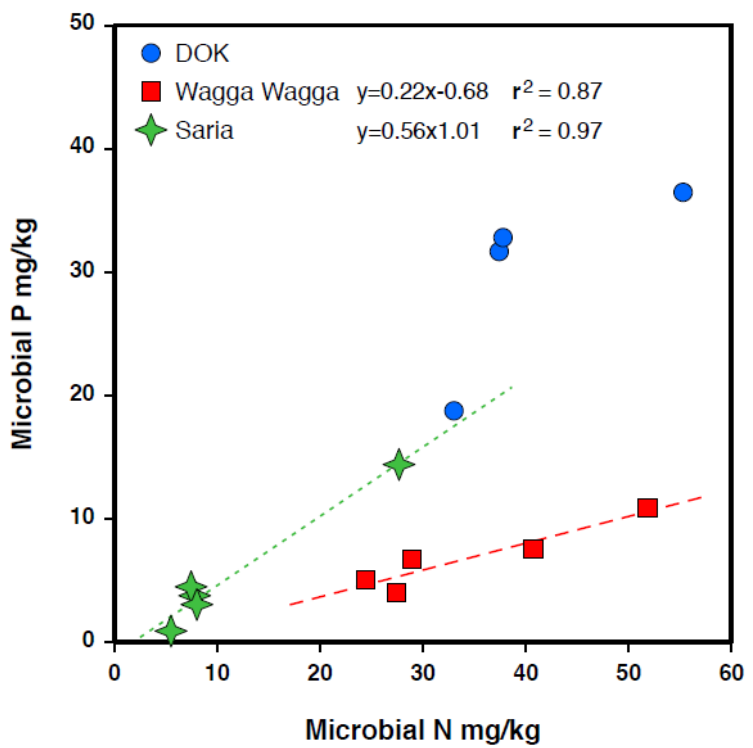

Figure 5. Relationship between soil microbial $\mathrm{N}$ and microbial $\mathrm{P}$ concentrations in the three field experiments. Points in blue represent DOK, points in red represent Wagga Wagga, and points in green represent Saria. The relationships in Saria and Wagga Wagga are statistically significant at $p<0.05$.

a low sorption capacity since it was dominated by quartz and kaolinite, a weak structural stability and very low nutrients concentrations, it was possible to see an effect of the $\mathrm{N}$ : $\mathrm{P}$ ratio of inputs on the $\mathrm{N}: \mathrm{P}$ ratios of the microorganisms and of the bulk soil. In contrast, in the soil with the highest clay content (Wagga Wagga), which had illite and iron oxides as sorbing surfaces, a good structural stability, and higher nutrient concentrations, no relation could be seen between the stoichiometric composition of the inputs and the soil pools. In this system, soil microorganisms were strongly homeostatic and their wide $\mathrm{C}: \mathrm{P}$ ratio was attributed to a large fungal biomass. It is therefore essential to consider element stabilization in soil when applying ecological stoichiometry principles to soil systems.

Ecological stoichiometry also requires proper information on element inputs and budgets in the ecosystem. In cropping systems, however, it is a challenge to obtain this information with sufficient precision. In particular, calculating $C$ inputs in cropped soils is a challenge not only because there is little information on root systems but also because organic fertilizers and yields can be very variable (see e.g. Table S1, showing the variability of manure composition, and Fig. S1, showing yield variability for Saria due to variable climatic conditions). Calculating budgets to assess what is left in soil is even more challenging, especially because of the difficulty to assess $\mathrm{C}$ losses from residues and native organic matter, e.g. through respiration or through dissolved organic carbon leaching (Hanson et al., 2000; Kalbitz et al., 2000). Quantifying $\mathrm{P}$ and $\mathrm{N}$ budgets in agroecosystems is also bound to a high level of uncertainty (Keller and Schulin, 2003; Oenema et al., 2003). Future studies on the ecological stoichiometry of cropped soils should include well-assessed C, N, and P inputs and budgets at field level.

\section{Conclusions}

This is the first paper reporting the effect of long-term inputs on the $\mathrm{C}: \mathrm{N}: \mathrm{P}$ ratios of bulk soil, and soil organic and microbial pools in cropped soils. Our results confirm that the $\mathrm{C}: \mathrm{N}: \mathrm{P}$ ratio of agricultural inputs and the $\mathrm{C}, \mathrm{N}$, and $\mathrm{P}$ budgets have limited impacts on the $\mathrm{C}: \mathrm{N}: \mathrm{P}$ ratio of soil pools, while element inputs and budgets strongly affect the concentrations of individual elements. Depending on soil proper- 
ties such as texture, mineralogy, structural stability, and nutrient status, the N:P ratios of inputs and of the total soil pools can be mirrored in the $\mathrm{N}: \mathrm{P}$ ratio of the soil microbial biomass (low sorbing, nutrient-poor soil) or not (high sorbing, nutrient-rich soil). We conclude that the study of $\mathrm{C}, \mathrm{N}$, and $\mathrm{P}$ ratios is important to understand the functioning of cropped soils in the long term, but that it must be coupled with a precise assessment of element inputs and budgets in the system and a good understanding of the ability of soils to stabilize $\mathrm{C}, \mathrm{N}$, and $\mathrm{P}$ compounds.

Our study can be seen as a first step towards an approach integrating $\mathrm{C}, \mathrm{N}$, and $\mathrm{P}$ cycling in agroecosystems since, to our knowledge, no other study has analysed the effects of all $\mathrm{C}, \mathrm{N}$, and $\mathrm{P}$ inputs and budgets on total, organic, and microbial $\mathrm{C}: \mathrm{N}: \mathrm{P}$ ratios in cropped soils. This type of approach might gain momentum in the future as it becomes evident that $\mathrm{C}, \mathrm{N}$, and $\mathrm{P}$ inputs and outputs from agricultural systems must be considered jointly (i) to provide tools to increase - currently low - N and P use efficiencies (Vitousek et al., 2009), (ii) to understand the effect of element losses on the pollution of water bodies (Woodward et al., 2012), and (iii) to improve $\mathrm{C}$ sequestration (Fernández-Martínez et al., 2014; Richardson et al., 2014). Ultimately, stoichiometric approaches should also take into account other elements, in particular those having a strong impact on $\mathrm{C}, \mathrm{N}$, and $\mathrm{P}$ cycling such as $\mathrm{Mo}, \mathrm{Fe}$, and $\mathrm{V}$, which are important co-factors for $\mathrm{N}_{2}$ fixation in free-living bacteria (Bellenger et al., 2011).

\section{The Supplement related to this article is available online at doi:10.5194/soil-2-83-2016-supplement.}

Acknowledgements. The authors thank the Swiss Agency for Development and Cooperation and ETH global for funding the research work of D. I. Kiba and O. Y. A. Traoré through RFPP grants as well as the scientists and technicians of INERA who have been taking care of the Saria field experiment. We also acknowledge the scientists and technicians of the Swiss Federal Research stations on agricultural research (nowadays Agroscope) and the Research Institute of Organic Farming (FiBL) for taking care of the DOK field experiment. We also thank M. Conyers and others at the Agricultural Research Institute in Wagga Wagga for maintaining the trial. We finally thank D. Tessier for the mineralogical analysis of clay fractions from the DOK field experiment, and W. Dougherty, G. Li, A. McNeill, and M. Unkovich for additional information on legume systems and potential nutrient losses from the Wagga Wagga trial.

Edited by: C. Rumpel

\section{References}

Ågren, G. I.: Stoichiometry and nutrition of plant growth in natural communities, Ann. Rev. Ecol. Evol. Syst., 39, 153-70, 2008.

Bellenger, J.-P., Wichard, T., Xu, Y., and Kraepiel, A. M. L.: Essential metals for nitrogen fixation in a free-living $\mathrm{N}_{2}$-fixing bacterium: chelation, homeostasis and high use efficiency, Environ. Microbiol., 13, 1395-1411, 2011.

Bonzi, M.: Evaluation et déterminisme du bilan de l'azote en sols cultivés du centre Burkina Faso: Etude par traçage isotopique ${ }^{15} \mathrm{~N}$ au cours d'essais en station et en milieu paysan. Thèse de Doctorat Unique en Sciences Agronomique, INPL/ENSAIA, Nancy, France, 2002.

Bosshard, C.: Nitrogen dynamics in organic and conventional cropping systems, PhD dissertation, ETH No. 17329, Swiss Federal Institute of Technology ETH, Zurich, Switzerland, 2007.

Bosshard, C., Frossard, E., Dubois, D., Mäder, P., Manolov, I., and Oberson, A.: Incorporation of ${ }^{15} \mathrm{~N}$-labeled amendments into physically separated soil organic matter fractions, Soil Sci. Soc. Am. J., 72, 949-959, 2008.

Bowman, R. A. and Moir, J. O.: Basic EDTA as an extractant for soil organic phosphorus, Soil Sci. Soc. Am. J., 57, 1516-1518, 1993.

Bünemann, E. K., Heenan, D. P., Marschner, P., and McNeill, A. M.: Long-term effects of crop rotation, stubble management and tillage on soil phosphorus dynamics, Aust. J. Soil Res., 44, 611618, 2006.

Bünemann, E. K., Smernik, R. J., Doolette, A. L., Marschner, P., Stonor, R., Wakelin, S. A., and McNeill, A. M.: Forms of phosphorus in bacteria and fungi isolated from two Australian soils, Soil Biol. Biochem., 40, 1908-1915, 2008a.

Bünemann, E. K., Marschner, P., Smernik, R. J., Conyers, M., and McNeill, A. M.: Soil organic phosphorus and microbial community composition as affected by 26 years of different management strategies, Biol. Fert. Soils, 44, 717-726, 2008 b.

Bünemann, E. K., Prusisz, B., and Ehlers, K.: Characterization of phosphorus forms in soil microorganisms, in: Phosphorus in action - Biological processes in soil phosphorus cycling, edited by: Bünemann, E. K., Oberson, A., and Frossard, E., Soil Biology Vol. 26, Springer, Heidelberg, 37-57, 2011.

Chan, K. Y. and Heenan, D. P.: Effects of lupin on soil properties and wheat production, Aust. J. Agr. Res., 44, 1971-1984, 1993.

Chan, K. Y., Roberts, W. P., and Heenan, D. P.: Organic carbon and associated soil properties of a Red Earth after 10 years of rotation under different stubble and tillage practices, Aust. J. Soil Res., 30, 71-83, 1992.

Chen, X., Daniell, T. J., Neilson, R., O’Flaherty, V., and Griffiths B. S.: Microbial and microfaunal communities in phosphorus limited, grazed grassland change composition but maintain homeostatic nutrient stoichiometry, Soil Biol. Biochem. 75, 94-101, 2014.

Cleveland, C. C. and Liptzin, D.: C: N : P stoichiometry in soil: is there a "Redfield ratio" for the microbial biomass? Biogeochemistry, 85, 235-252, 2007.

Cotrufo, M. F., Wallenstein, M. D., Boot, C. M., Denef, K., and Paul, E.: The microbial efficiency-matrix stabilization (MEMS) framework integrates plant litter decomposition with soil organic matter stabilization: do labile plant inputs form stable soil organic matter?, Glob. Change Biol., 19, 988-995, 2013. 
Dutartre, P., Bartoli, F., Andreux, F., Portal, J. M., and Ange, A.: Influence of content and nature of organic matter on the structure of some sandy soils from West Africa, Geoderma, 56, 459-478, 1993.

Elser, J. J., Fagan, W. F., Kerkhoff, A. J., Swenson, N. G., and Enquist, B. J.: Biological stoichiometry of plant production: metabolism, scaling and ecological response to global change, New Phytol., 186, 593-608, 2010.

Esperschütz, J., Gattinger, A., Mäder, P., Schloter, M., and Fliessbach, A.: Response of soil microbial biomass and community structures to conventional and organic farming systems under identical crop rotations, FEMS Microbiol. Ecol., 61, 26-37, 2007.

Fanin, N., Fromin, N., Buatois, B., and Hättenschwiler, S.: An experimental test of the hypothesis of non-homeostatic consumer stoichiometry in a plant litter microbe system, Ecol. Lett., 16, 764-772, 2013.

FAO, ISRIC, ISSS: World reference base for soil resources, FAO, Rome, 1998.

Fernández-Martínez, M., Vicca, S., Janssens, I. A., Sardans, J., Luyssaert, S., Campioli, M., Chapin III, F. S., Ciais, P., Malhi, Y., Obersteiner, M., Papale, D., Piao, S. L., Reichstein, M., Rodà, F., and Peñuelas, J.: Nutrient availability as the key regulator of global forest carbon balance, Nat. Clim. Chang., 4, 471-476, 2014.

Flisch, R., Sinaj, S., Charles, R., and Richner, W.: GRUDAF, Grundlagen für die Düngung im Acker- und Futterbau, Agrarforschung, 16, 1-100, 2009.

Frossard, E., Condron, L. M., Oberson, A., Sinaj, S., and Fardeau, J. C.: Processes governing phosphorus availability in temperate soils, J. Environ. Qual., 29, 15-23, 2000.

Frostegård, Å. and Bååth, E.: The use of phospholipid fatty acid analysis to estimate bacterial and fungal biomass in soil, Biol. Fert. Soils, 22, 59-65, 1996.

Gressel, N., McColl, J. G., Preston, C. M., Newman, R. H., and Powers, R. F.: Linkages between phosphorus transformations and carbon decomposition in a forest soil, Biogeochemistry, 33, 97123, 1996.

Griffiths, B. S., Spilles, A., and Bonkowski, M.: C:N:P stoichiometry and nutrient limitation of the soil microbial biomass in a grazed grassland site under experimental $\mathrm{P}$ limitation or excess, Ecol. Process., 1, doi:10.1186/2192-1709-1-6, 2012.

Güsewell, S.: N :P ratios in terrestrial plants: variation and functional significance, New Phytol., 164, 243-266, 2004.

Hanson, P. J., Edwards, N. T., Garten, C. T., and Andrews, J. A.: Separating root and soil microbial contributions to soil respiration: A review of methods and observations, Biogeochemistry, 48, 115-146, 2000.

Harrison, A. F.: Soil organic phosphorus. A review of world literature, CAB international, Oxon, UK, 1987.

Hartman, W. H. and Richardson, C. J.: Differential nutrient limitation of soil microbial biomass and metabolic quotients $\left(\mathrm{qCO}_{2}\right)$ : Is there a biological stoichiometry of soil microbes? PLOS ONE, 8, e57127, doi:10.1371/journal.pone.0057127, 2013.

He, Z. L., Wu, J., O'Donnell, A. G., and Syers, J. K.: Seasonal responses in microbial biomass carbon, phosphorus and sulphur in soils under pasture, Biol. Fert. Soils, 24, 421-428, 1997.
Heenan, D. P. and Chan, K. Y.: The long-term effects of rotation, tillage and stubble management on soil mineral nitrogen supply to wheat, Aust. J. Soil Res., 30, 977-988, 1992.

Heenan, D. P. and Taylor, A. C.: Soil pH decline in relation to rotation, tillage, stubble retention and nitrogen fertilizer in SE Australia, Soil Use Manage., 11, 4-9, 1995.

Heenan, D. P., Taylor, A. C., Cullis, B. R., and Lill, W. J.: Longterm effects of rotation, tillage and stubble management on wheat production in southern NSW, Aust. J. Agric. Res., 45, 93-117, 1994.

Heenan, D. P., McGhie, W. J., Thomson, F. M., and Chan, K. Y.: Decline in soil organic carbon and total nitrogen in relation to tillage, stubble management, and rotation, Aust. J. Exp. Agr., 35, 877-884, 1995.

Heenan, D. P., Taylor, A. C., Chan, K. Y., McGhie, W. J., Collins, D., and Lill, W. J.: The impact of long-term rotation, tillage and stubble management on lupin (Lupinus angustifolius) productivity, Field Crop Res., 67, 11-23, 2000.

Heenan, D. P., Chan, K. Y., and Knight, P. G.: Long-term impact of rotation, tillage and stubble management on the loss of soil organic carbon and nitrogen from a Chromic Luvisol, Soil Tillage Res., 76, 59-68, 2004.

Hessen, D. O., Elser, J. J., Sterner, R. W., and Urabe, J.: Ecological stoichiometry: An elementary approach using basic principles, Limnol. Oceanogr., 58, 2219-2236, 2013.

Heuck, C., Weig, A., and Spohn, M.: Soil microbial biomass $\mathrm{C}: \mathrm{N}: \mathrm{P}$ stoichiometry and microbial use of organic phosphorus, Soil Biol. Biochem., 85, 119-129, 2015.

Hien, E.: Dynamique du carbone dans un Acrisol ferrique du Centre Ouest Burkina: Influence des pratiques culturales sur le stock et la qualité de la matière organique, Thèse de doctorat, Ecole Nationale Supérieure Agronomique de Montpellier, Montpellier, France, 2004.

Kalbitz, K., Solinger, S., Park, J. H., Michalzik, B., and Matzner, E.: Controls on the dynamics of dissolved organic matter in soils: A review, Soil Sci., 165, 277-304, 2000.

Keller, A. and Schulin, R.: Modelling heavy metal and phosphorus balances for farming systems, Nutr. Cycl. Agroecosys., 66, 271284, 2003.

Keller, M., Oberson, A., Annaheim, K. E., Tamburini, F., Mäder, P., Mayer, J., Frossard, E., and Bünemann, E. K.: Phosphorus forms and enzymatic hydrolysability of organic phosphorus in soils after 30 years of organic and conventional farming, J. Plant Nutr. Soil Sc., 175, 385-393, 2012.

Kertesz, M. A. and Frossard, E.: Biological cycling of inorganic nutrients and metals in soils and role in soil biogeochemistry, in: Soil Microbiology, Ecology and Biochemistry, edited by: Paul, E. A., 4th Edn., Elsevier, 471-503, 2015.

Kiba, D. I.: Diversité des modes de gestion de la fertilité des sols et de leurs effets sur la qualité des sols et la production de culture en zones urbaine, périurbaine, et rurale au Burkina Faso, Thèse de doctorat, Institut du développement rural, université polytechnique de Bobo Dioulasso, Bobo Dioulasso, Burkina Faso, 2012.

Kirkby, C. A., Kirkegaard, J. A., Richardson, A. E., Wade, L. J., Blanchard, C., and Batten, G.: Stable soil organic matter: A comparison of $\mathrm{C}: \mathrm{N}: \mathrm{P}: \mathrm{S}$ ratios in Australian and other world soils, Geoderma, 163, 197-208, 2011.

Kirkby, C. A., Richardson, A. E., Wade, L. J., Batten, G. D., Blanchard, C., and Kirkegaard, J. A.: Carbon-nutrient stoichiometry 
to increase soil carbon sequestration, Soil Biol. Biochem., 60, 77-86, 2013.

Kirkby, C. A., Richardson, A. E., Wade, L. J., Passioura, J. B., Batten, G. D., Blanchard, C., and Kirkegaard, J. A.: Nutrient availability limits carbon sequestration in arable soils, Soil Biol. Biochem., 68, 402-409, 2014.

Leifeld, J., Reiser, R., and Oberholzer, H.-R.: Consequences of conventional versus organic farming on soil carbon: Results from a 27-year field experiment, Agron. J., 101, 1204-1218, 2009.

Lesschen, J. P., Stoorvogel, J. J., Smaling, E. M. A., Heuvelink, G. B. M., and Veldkamp, A.: A spatially explicit methodology to quantify soil nutrient balances and their uncertainties at the national level, Nutr. Cycl. Agroecosyst., 78, 111-131, 2007.

Loladze, I. and Elser, J. J.: The origins of the Redfield nitrogento-phosphorus ratio are in a homoeostatic protein-to-rRNA ratio, Ecol. Lett., 14, 244-250, 2011.

Lompo, F.: Effets induits des modes de gestion de la fertilité sur les états du phosphore et la solubilisation des phosphates naturels dans deux sols acides du Burkina Faso, thèse doctorat d'Etat, Université de Cocody, Abidjan, Côte d'Ivoire, 2009.

Mäder, P., Fließbach, A., Dubois, D., Gunst, L., Fried, P., and Niggli, U. Soil fertility and biodiversity in organic farming, Science, 296, 1694-1697, 2002.

Mäder, P., Fliessbach, A., Dubois, D., Gunst, L., Jossi, W., Widmer, F., Oberson, A., Frossard, E., Oehl, F., Wiemken, A., Gattinger, A., and Niggli, U.: The DOK experiment (Switzerland), in: Long-term field experiments in organic farming, edited by: Raupp, J., Pekrun, C., Oltmanns, M., and Köpke, U., Verlag Dr. Köster, Berlin, 41-58, 2006.

Makino, W., Cotner, J. B., Sterner, R. W., and Elser, J. J.: Are bacteria more like plants or animals? Growth rate and resource dependence of bacterial C:N:P stoichiometry, Funct. Ecol., 17, 121130, 2003.

McGill, W. B. and Cole, C. V.: Comparative aspects of cycling of organic C, N, S and P through soil organic matter, Geoderma, 26, 267-286, 1981.

Miltner, A., Bombach, P., Schmidt-Brücken, B., and Kästner, M.: SOM genesis: microbial biomass as a significant source, Biogeochemistry, 111, 41-55, 2012.

Mooshammer, M., Wanek, W., Zechmeister-Boltenstern, S., and Richter, A.: Stoichiometric imbalances between terrestrial decomposer communities and their resources: mechanisms and implications of microbial adaptations to their resources, Front. Microbiol., 5, doi:10.3389/fmicb.2014.00022, 2014.

Mouginot, C., Kawamura, R., Matulich, K. L., Berlemont, R., Allison, S. D., Amend, A. S., and Martiny, A. C.: Elemental stoichiometry of Fungi and Bacteria strains from grassland leaf litter, Soil Biol. Biochem., 76, 278-285, 2014.

Mulder, C., Ahrestani, F. S., Bahn, M., Bohan, D. A., Bonkowski, M., Griffiths, B. S., Guicharnaud, R. A., Kattge, J., Krogh, P. H., Lavorel, S., Lewis, O. T., Mancinelli, G., Naeem, S., Peñuelas, J., Poorter, H., Reich, P. B., Rossi, L., Rusch, G. M., Sardans, J., and Wright, I. J.: Connecting the green and brown worlds: allometric and stoichiometric predictability of above- and belowground networks, Adv. Ecol. Res., 49, 69-175, 2013.

Nesper, M., Bünemann, E. K., Fonte, S. J., Rao, I. M., Velásquez, J. E., Ramirez, B., Hegglin, D., Frossard, E., and Oberson, A.: Pasture degradation decreases organic $P$ content of tropical soils due to soil structural decline, Geoderma, 257-258, 123-133, 2015.
Oberson, A., Frossard, E., Bühlmann, C., Mayer, J., Mäder, P., and Lüscher, A.: Nitrogen fixation and transfer in grass-clover leys under organic and conventional cropping systems, Plant Soil, 371, 237-255, 2013.

Oehl, F., Oberson, A., Tagmann, H. U., Besson, J. M., Dubois, D., Mäder, P., Roth, H.-R., and Frossard, E.: Phosphorus budget and phosphorus availability in soils under organic and conventional farming, Nutr. Cycl. Agroecosyst., 62, 25-35, 2002.

Oenema, O., Kros, H., and de Vries, W.: Approaches and uncertainties in nutrient budgets: implications for nutrient management and environmental policies, Eur. J. Agron., 20, 3-16, 2003.

Ognalaga, M., Frossard, E., and Thomas, F.: Glucose-1-phosphate and myo-inositol hexaphosphate adsorption mechanisms on goethite, Soil Sci. Soc. Am. J., 58, 332-337, 1994.

Parton, W. J., Stewart, J. W. B., and Cole, C. V.: Dynamics of C, N, $\mathrm{P}$ and $\mathrm{S}$ in grassland soils - a model, Biogeochemistry, 5, 109131, 1988.

Parton, W. J., Del Grosso, S. J., Plante, A. F., Adair, E. C., and Lutz, S. M.: Modeling the dynamics of soil organic matter and nutrient cycling, in: Soil Microbiology, Ecology and Biochemistry, edited by: Paul, E. A., 4th Edn., 505-537, 2015.

Pieri, C.: Fertilité des terres de savanes, Bilan de trente ans de recherche et de développement agricoles au sud du Sahara, Ministère de la coopération et du Développement, et CIRAD-IRAT, Paris, France, 1989.

Redfield, A. C.: The biological control of chemical factors in the environment, Am. Sci., 46, 205-221, 1958.

Richardson, A. E., Kirkby, C. A., Banerjee, S., and Kirkegaard, J. A.: The inorganic nutrient cost of building soil carbon, Carbon Manag., 5, 265-268, 2014.

Saunders, W. M. H. and Williams, E. G.: Observations on the determination of total organic phosphorus in soils, J. Soil Sci., 6, 254-267, 1955.

Schmidt, M. W. I., Torn, M. S., Abiven, S., Dittmar, T., Guggenberger, G., Janssens, I. A., Kleber, M., Kögel-Knabner, I., Lehmann, J., Manning, D. A. C., Nannipieri, P., Rasse, D. P., Weiner, S., and Trumbore, S. E.: Persistence of soil organic matter as an ecosystem property, Nature, 478, 49-56, 2011.

Sedogo, M. P.: Evolution des sols ferrugineux lessivés sous culture: incidence des modes de gestion sur la fertilité, Thèse de Doct. D'Etat, FAST, Université Nationale de Côte d'Ivoire, Côte d'Ivoire, 1993.

Siegrist, S., Schaub, D., Pfiffner, L., and Mäder, P.: Does organic agriculture reduce soil erodibility? The results of a long-term field study on loess in Switzerland, Agr. Ecosyst. Environ., 69, 253-264, 1998.

Sinaj, S., Frossard, E., and Fardeau, J. C.: Isotopically exchangeable phosphate in size fractionated and unfractionated soils, Soil Sci. Soc. Am. J., 61, 1413-1417, 1997.

Six, J., Bossuyt, H., Degryze, S., and Denef, K.: A history of research on the link between (micro)aggregates, soil biota, and soil organic matter dynamics, Soil Tillage Res., 79, 7-31, 2004.

Six, J., Frey, S. D., Thiet, R. K., and Batten, K. M.: Bacterial and fungal contributions to carbon sequestration in agroecosystems, Soil Sci. Soc. Am. J., 70, 555-569, 2006.

Spiess, E., Prasuhn, V., and Stauffer, W.: Influence of organic and mineral fertilizers on nutrient leaching, Agrarforschung Schweiz, 2, 376-381, 2011. 
Sterner, R. W. and Elser, J. J.: Ecological Stoichiometry: The biology of elements from molecules to the biosphere, Princeton, $\mathrm{NJ}$, Princeton University Press, USA, 2002.

Stewart, J. W. B. and Tiessen, H.: Dynamics of soil organic phosphorus, Biogeochemistry, 4, 41-60, 1987.

Traoré, O. Y. A., Kiba, D. I., Arnold, M. C., Fliessbach, A., Oberholzer, H., Nacro, H. B., Lompo, F., Oberson, A., Frossard, E., and Bünemann, E. K.: Fertilization practices alter microbial nutrient limitations in a Ferric Acrisol, Biol. Fert. Soils, 52, 177189, doi:10.1007/s00374-015-1061-9, 2016.

Trivedi, P., Anderson, I. C., and Singh, B. K.: Microbial modulators of soil carbon storage: integrating genomic and metabolic knowledge for global prediction, Trends Microbiol., 21, 641$651,2013$.

Van Groenigen, K. J., Six, J., Hungate, B. A., de Graaff, M. A., van Breemen, N., and van Kessel, C.: Element interactions limit soil carbon storage, Proc. Natl. Acad. Sci. USA, 103, 6571-6574, 2006.

Vanlauwe, B., Bationo, A., Chianu, J., Giller, K. E., Merckx, R., Mokwunye, U., Ohi-okpehai, O., Pypers, P., Tabo, R., Shepherd, K. D., Smaling, E. M. A., Woomer, P. L., and Sanginga, N.: Integrated soil fertility management. Operational definition and consequences for implementation and dissemination, Outlook Agr., 39, 17-24, 2010.

Van Mooy, B. A. S., Rocap, G., Fredricks, H. F., Evans, C. T., and Devol, A. H.: Sulfolipids dramatically decrease phosphorus demand by picocyanobacteria in oligotrophic marine environments, Proc. Natl. Acad. Sci. USA, 6, 8607-8612, 2006.

Vitousek, P. M., Naylor, R., Crews, T., David, M. B., Drinkwater, L. E., Holland, E., Johnes, P. J., Katzenberger, J., Martinelli, L. A., Matson, P. A., Nziguheba, G., Ojima, D., Palm, C. A., Robertson, G. P., Sanchez, P. A., Townsend, A. R., and Zhang, F. S.: Nutrient imbalances in agricultural development, Science, 324, 1519-1520, 2009.
Von Lützow, M., Kögel-Knaber, I., Ekschmitt, K., Matzner, E., Guggenberger, G., Marschner, B., and Flessa, H. Stabilization of organic matter in temperate soils: mechanisms and their relevance under different soil conditions - a review, Eur. J. Soil Sci., 57, 426-445, 2006.

Vrede, K., Heldal, M., Norland, S., and Bratbak, G.: Elemental composition $(\mathrm{C}, \mathrm{N}, \mathrm{P})$ and celle volume of exponentially growing and nutrient-limited bacterioplankton, Appl. Environ. Microbiol., 68, 2965-2971, 2002.

Wang, X. M., Liu, F., Tan, W. F., Li, W., Feng, X. H., and Sparks, D. L.: Characteristics of phosphate adsorption-desorption onto ferrihydrite: comparison with well-crystalline Fe (hydr)oxides, Soil Sci., 178, 1-11, 2013.

Woodward, G., Gessner, M. O., Giller, P. S., Gulis, V., Hladyz, S., Lecerf, A., Malmqvist, B., McKie, B. G., Tiegs, S. D., Cariss, H., Dobson, M., Elosegi, A., Ferreira, V., Graca, M. A. S., Fleituch, T., Lacoursiere, J. O., Nistorescu, M., Pozo, J., Risnoveanu, G., Schindler, M., Vadineanu, A., Vought, L. B. M., and Chauvet, E.: Continental-scale effects of nutrient pollution on stream ecosystem functioning, Science, 336, 1438-1440, 2012.

Xu, X., Thornton, P. E., and Post, W. M.: A global analysis of soil microbial biomass carbon, nitrogen and phosphorus in terrestrial ecosystems, Global Ecol. Biogeogr., 22, 737-749, 2013.

Zhang, G. S., Chan, K. Y., Oates, A., Heenan, D. P., and Huang, G. B.: Relationship between soil structure and runoff/soil loss after 24 years of conservation tillage, Soil Till. Res., 92, 122 128, 2007.

Zida, Z., Ouédraogo, E., Mando, A., and Stroosnijder, L.: Termite and earthworm abundance and taxonomic richness under longterm conservation soil management in Saria, Burkina Faso, West Africa, Appl. Soil Ecol., 51, 122-129, 2011.

Zougmoré, R., Mando, A., Stroosnijder, L., and Guillobez, S.: Nitrogen flows and balances as affected by water and nutrient management in a sorghum cropping system of semiarid Burkina Faso, Field Crop Res., 90, 235-244, 2004. 